\title{
Transforming Scholarship
}

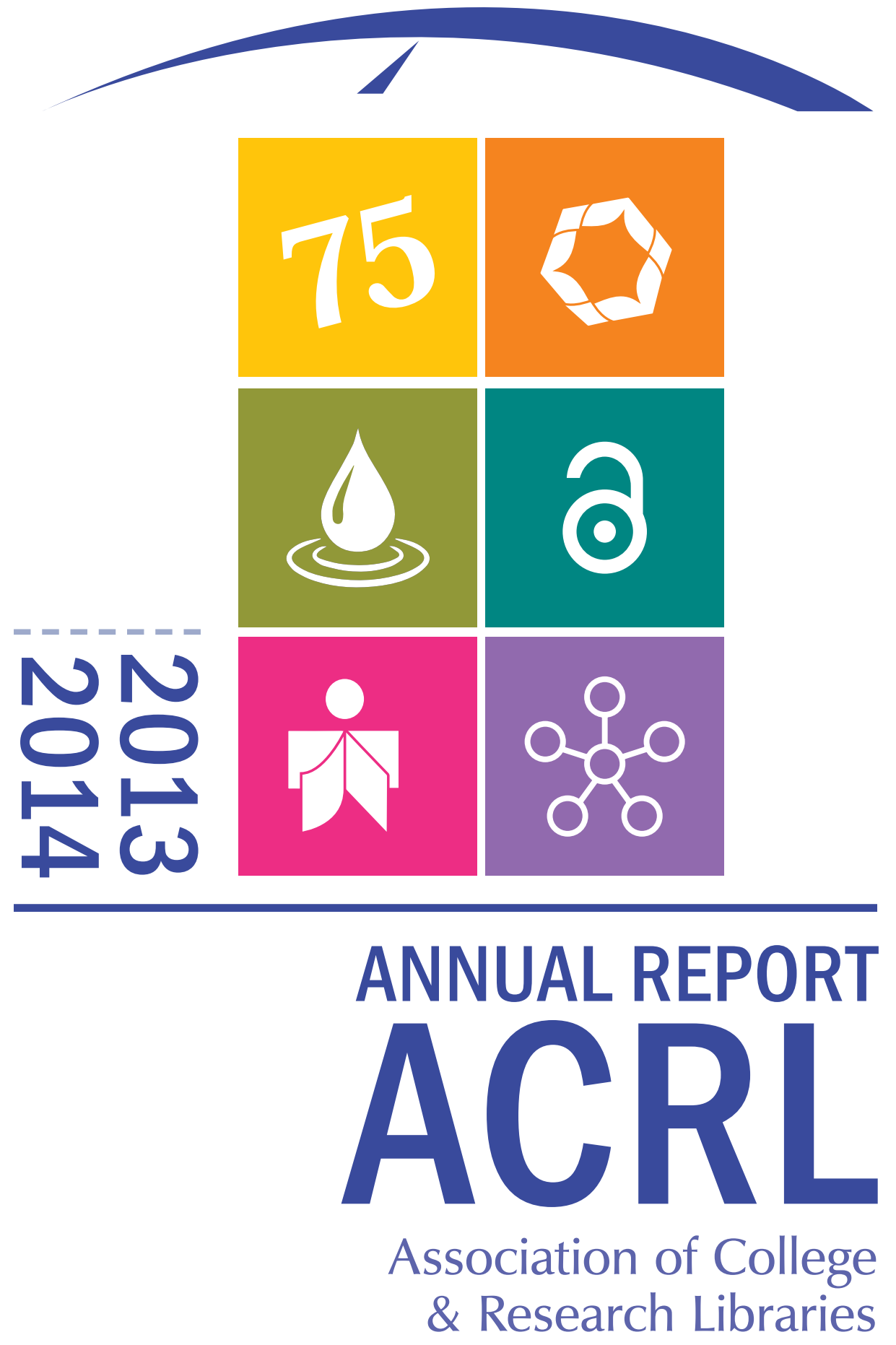




\section{Nesssige from the President}

\section{Trevor A. Dawes \\ ACRL's 75 th President}

What a year this has been!

I started the year very excited to lead the Board of Directors and the association as we continued the great work for which ACRL is known. But I did not expect to have my expectations for the year to have been surpassed.

I have been absolutely delighted by the number of libraries and librarians that

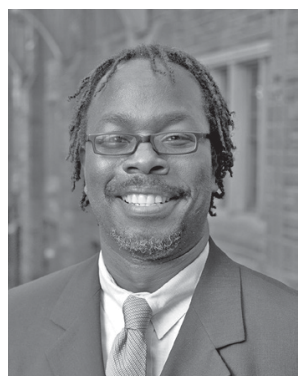
have expressed interest in playing an active role in delivering financial literacy

education (FLE) in their communities. We followed up a forum on financial literacy at the 2014 ALA Midwinter Meeting with a successful program at the ALA Annual Conference in Las Vegas. I am so pleased that 700 libraries participated in the ALA/Federal Reserve Bank of Chicago-sponsored Money Smart Week activities. This total includes 77 academic libraries-up from 35 libraries the previous year. I look forward to additional programs and information about FLE as ALA continues to coordinate efforts with several divisions, including ACRL, on this very important topic.

This year we also tackled some new and emerging issues. The task force charged with reviewing the Information Literacy Competency Standards for Higher Education continued their work, and we are expecting a report from them in the next fiscal year. Through the process of revising these standards, which are very important to ACRL and to our members, we asked for and received a large amount of feedback from our members. We look forward to receiving the report of the task force.

To help support our members as they grapple with issues around data management on their campuses, ACRL held a forum on data management at the 2014 ALA Midwinter Meeting in Philadelphia. This forum was followed up with a survey of the members of the Digital Curation Interest Group to better understand the needs of the community. As we continue to gather information, we will also develop programming and educational opportunities designed to serve our members well.

Activities related to our Value of Academic Libraries initiative continue to be strong. A new cohort of libraries, including my own at Washington University in St. Louis, began their participation in the Assessment in Action grant-funded program this year. They join the first cohort in demonstrating, with campus partners, the impact libraries have on student success.

I've continued to be excited by my chapter visits. Meeting with ACRL members across the country and learning about issues they're facing in their communities have helped to validate the work we do to support your work. As a member-driven association, we rely on learning about your needs, and the discussions I've had during my visits have been invaluable in gathering information. We are seeing some shifts in the roles that librarians play on campus, and we'll be hearing more about these new roles as the new ACRL president takes the helm. I look forward to learning even more about how our work is changing-and more importantly, to develop programs and services to meet these changing needs that arise as a result.

I am so proud to be a part of an association that is at once a leader and also responsive to our members. I thank you all, our members, for the wonderful opportunity to have served as president this past year! 


\section{Inntial Conference Progrimins}

\section{ACRL Programs at the 2014 ALA Annual Conference - Las Vegas -}

- AASL/ACRL Interdivisional Committee on Information Literacy - Common Core State Standards and General Education: Information Literacy Connects the Dots

- ANSS/EBSS - Supporting Community Transformation: Becoming a Community-Engaged Academic Library

- CLS - Science+Form=Function: The Impact of Neuroscience on Architecture \& Design

- DLS/ ULS - Leading from the Side: On, Off, and Within Your Campus

- Individual Proposal - Tenure-track Support Systems: Perceptions of Academic Librarians

- Individual Proposal - Get Writing! Overcome Procrastination, Remove Roadblocks, and Create a Map for Success

- Individual Proposal - Are You Taking a Gamble on Your Academic Library Career by Having a Baby (or Two)?

- Individual Proposal - Crash Course in Evaluation Research

- Individual Proposal - Librarians as Digital Leaders: Collaborating on the Development and Use of Digitized Collections

- Individual Proposal - Making Tenure: A Model for Collaborative Publishing

- Individual Proposal - Using Instructional Design Applications to Effectively Flip Library Instruction

- Individual Proposal - Virtual Reference with JoinMe

- IS - From Stumbling Blocks to Building Blocks: Using Threshold Concepts to Teach Information Literacy

- LES/SEES/WESS - "Embedded" Cultural Communities in Europe and the Americas: Challenges for Librarians

- Professional Values Committee - Surveillance

- President's Program - Financial Literacy at Your Library

- Publications Coordinating Committee - Libraries in the Publishing Game: New Roles from Content to Access

- Residency Interest Group - Stop Dreaming and Do It! Best Practices for Gaining Momentum, Developing and Maintaining a Successful Residency Program

- STS/Health Science Interest Group - Sticking with STEM: How the Academic Library Can Help to Retain Successful Students

- WGSS - Digital Humanities and Academic Libraries: Practice and Theory, Power, and Privilege 


\section{Nessige from the Vice-President}

\section{Karen Williams}

Vice-President/President-Elect

Ibegan my year as ACRL Vice-President/President-Elect at the same time I took on the role of dean of libraries at the University of Arizona. I was pleased to see how well ACRL's strategic priorities align with the strategic priorities of my institution and, more broadly, with academic libraries of all stripes. This alignment reflects a professional organization with its finger on the pulse of powerful changes in higher education and the ways in which these changes are impacting college and academic

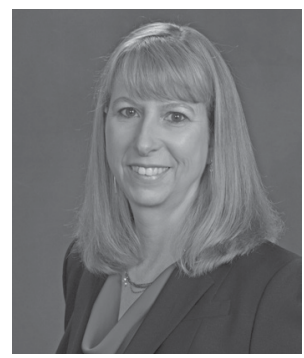
libraries.

At a time when many in higher education are providing support for open access and/or calling for reduced subscription costs, ACRL enacted our values by making College \& Research Libraries an open access journal, despite uncertainty about how it would be funded going forward. Since then, the extremely talented ACRL staff and Board of Directors have experimented with a number of services and strategies to produce new revenue streams including offering consulting services, online courses, live webcasts, and a development campaign to provide scholarships for attendance at ACRL 2015. The new ACRL-CHOICE webinars, made freely available through sponsorship from vendors and publishers, have been very popular. The staff at CHOICE are thinking creatively about what new services or publications they can offer in the future. Like many of our institutions, ACRL is forging new revenue streams while attending to the needs of constituents, in this case members.

In 2012, the ACRLBoard of Directors recommended a substantive revision of the Information Literacy Competency Standards for Higher Education. The Board appointed a task force which has been working since March 2013 charged with updating the document to "reflect the current thinking on such things as the creation and dissemination of knowledge, the changing global higher education and learning environment, the shift from information literacy to information fluency, and the expanding definition of information literacy to include multiple literacies, e.g., transliteracy, media literacy, digital literacy, etc." The task force has indeed produced a document very different in approach from the existing standards called a Framework for Information Literacy for Higher Education. As always, the task force was asked to solicit input on substantive drafts of the new document. Conversation around the Framework has been spirited; ranging from serious concern about using threshold concepts as the foundation for the Framework, to excitement about the new direction. A consultant for the Lumina Foundation commented, "I think that the Framework has real value for faculty engaged in rethinking curricula, including those doing so within a competency-based approach.”

I remember similar debates in 1995, when a proposal came forward for the Bibliographic Instruction Section to change its name to the Information Literacy Section. The resulting conversation was passionate and much more about the meaning of the work than the name of a section. The change in intention was captured well by Virginia Tiefel who noted, "[Information literacy] is an expansion of instruction as to objectives, materials and methods. It has evolved in the way that instruction evolved from library orientation into bibliographic instruction." Robust professional and scholarly conversations such as that in 1995 and the one taking place today are critical to the success of our teaching and learning efforts and I look forward to the comments on the third revision of the Framework. The input received to date has been invaluable to the task force, and your continued input will help the Board make decisions about the document going forward. This conversation will begin at Midwinter; no final decisions have been made yet.

In another important initiative, the Board and staff have put several processes into play to gather qualitative data about the needs of current, former, and prospective members and their perceptions of the benefit and value of ACRL membership. We'll be continuing this work in the coming year in order to increase our knowledge of memberneeds and desires and to shape offerings that will both retain current members and recruit new members. 


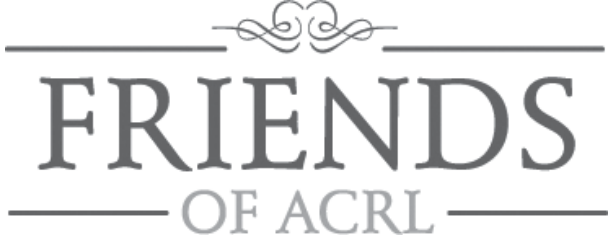

The Friends of ACRL donations support ACRL's mission in key areas, including the Advocacy Fund, Board Strategic Plan Initiative Fund, Innovative Programming Fund, Professional Development Fund, RBMS Scholarships Fund, and the William Moffett Memorial

Fund. Since the establishment of the Friends of ACRL, 512 donors have become Friends and contributed more than $\$ 161,000$ to demonstrate their support for its initiatives. Money from the Friends Funds has been used to provide scholarships for ACRL professional development activities and to support the ACRL awards program through publicity and the creation of special presidential awards.

Thanks to those listed below for contributing to the Friends of ACRL in FY14 (September 1, 2013 - August 31,2014). Founding Friends are shown in italics. A complete list of Founding Friends is available on the ACRL website at www.ala.org/acrl/aboutacrl /givetoacrl/donate/friendsfound. A list of contributors to the 75th Anniversary Kick Start the Future Scholarship Campaign can be found at http://acrl.ala.org/acrl75/?page_id=250.

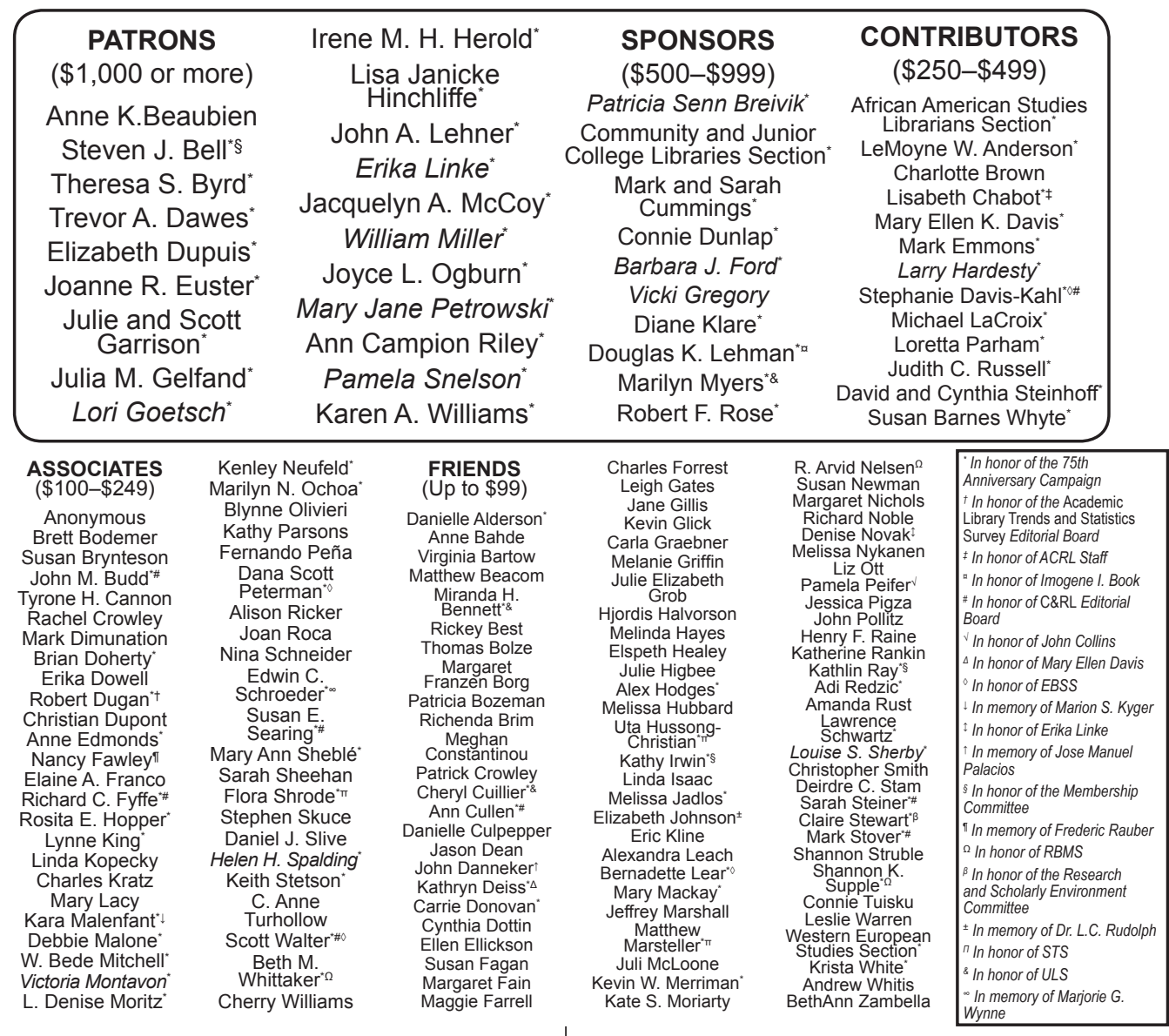




\section{Letter from the Axecutive lireetor}

\section{Mary Ellen K. Davis \\ ACRL Executive Director}

ACRL continued to make great progress on its Plan for Excellence and I invite you to learn more about our many accomplishments in the areas of the value of academic libraries, student learning, and the research and scholarly environment. I also want to share our work on an exciting initiative we launched this year in honor of ACRL's 75th anniversary, the Kick Start the Future campaign.

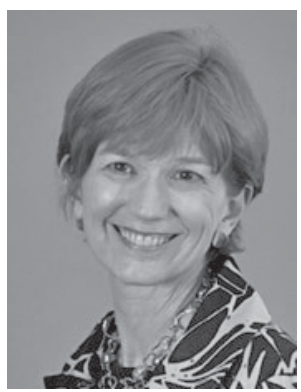

While planning for the anniversary celebrations was underway, ably led by a task force chaired by Pamela Snelson, the ACRL leadership embraced fundraising and decided that a fitting way to celebrate ACRL's 75th anniversary was to provide more scholarships for librarians new to the profession and library school students to attend the ACRL 2015 Conference.

With that decision a campaign was born: ACRL leaders challenged our members to contribute $\$ 50,000$ to match the amount of scholarship funding budgeted for the ACRL 2015 Conference, thus providing $\$ 100,000$ in support.

The ACRL Board of Directors and Budget \& Finance Committee stepped up with lead gifts. The ACRL presidents and I worked during the silent phase of the campaign in the spring, calling former presidents and inviting them to participate. I had the pleasure of reconnecting with a number of ACRL past presidents from the 1970s and 1980s. While long retired and some are in their 90s, they were delighted to hear from ACRL and happy to pledge support to the campaign. It was fascinating to connect with the ACRL of 40 years ago and learn about the opportunities and challenges our past leaders faced. Did you know that LeMoyne Anderson served as president of ACRL (1979-1980) and the Association of Research Libraries at the same time! Another, Connie Dunlap (1976-77) had to recruit a new executive director and a new editor and publisher for CHOICE, as well as work with ALA on the development of the Huron Plaza Building (which now provides office space for a majority of the ALA staff).

Besides a capacity for leadership what do these individuals have in common? They highly valued ACRL for its contributions to the profession and cherish their memories of the people they met through ACRL. They were more than delighted to contribute to ACRL's Kick Start the Future campaign so that they could continue to give back and engage the next generation in the joys of professional involvement.

In June we appealed to ACRL Leadership Council. They helped us to refine the case statement for the campaign and fifteen ACRL committees, sections, and chapters are now working to raise at least $\$ 635$ to support a named scholarship with support from our campaign director, Steven J. Bell.

We appreciate your gifts and want our donors to know how much their support is valued. As of this writing we are at $\$ 44,000$ of our $\$ 50,000$ goal. Every contribution helps. It is not too late. If you have not yet participated in the campaign, I encourage you to "Kick Start the Future" and invest in the profession's future leaders (and their libraries) as they seek to advance learning and transform scholarship in the 21 st century. With your contribution (of any amount), we can 


\section{lORL by the Numbers}

ensure the future vitality of the profession, the association, and the diversity of our conference. Complete information on the campaign is available at http://acrl.ala.org/acrl75/?page_id=244.

ACRL is a vibrant, generous, and caring community. Knowledge and expertise are freely shared in the spirit of serving our communities in the best possible ways. I want to take this opportunity to thank the many members, colleagues, and staff for the contributions they have made (and continue to make) to this exceptional community.

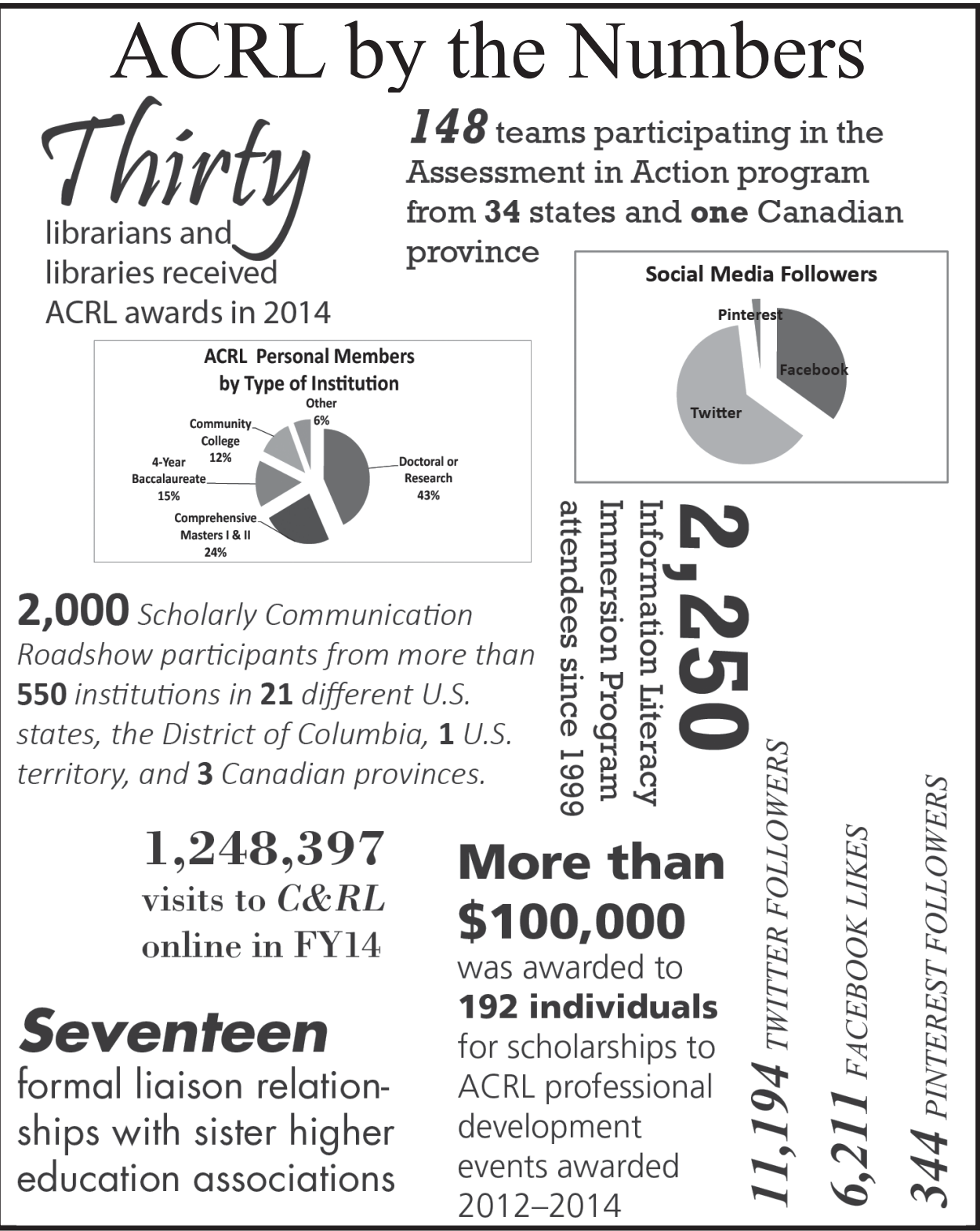




\section{ACRL 75th Anniversary}

In May 2014, ACRL began a yearlong celebration of the association's 75th anniversary. Following a new constitution that included the creation of self-governing divisions within the association, the ALA Council recognized its first division on May 31, 1940. That inaugural division was ACRL, the Association of College and Reference Libraries. It was not until 1956 that the word Research was substituted for Reference - in response to the Reference Libraries Section of ACRL joining a newly formed Library Reference Services Division.

In spring 2012, the ACRL Board of Directors created a task force to plan celebratory activities related to ACRL's 75th anniversary. Current, upcoming, and ongoing anniversary activities include a regular column in $C \& R L N e w s$, profiles of past ACRL presidents on the 75th anniversary

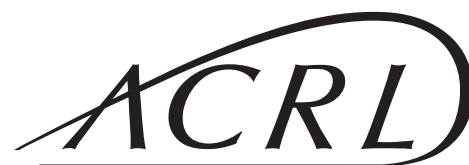

75 TH ANNIVERSARY website, a fundraising campaign to support scholarships to the ACRL 2015 conference, an upcoming special issue of $C \& R L$ featuring crowdsourced seminal articles from the journal's history, an invited paper-New Roles for the Road Ahead: Essays Commissioned for ACRL's 75th Anniversary, a time capsule, and multiple events at ACRL 2015.

Complete details on the celebration are available on the ACRL 75th Anniversary website at http://acrl.ala.org/acrl75.

\section{ACRL's Plan for Excellence}

This report highlights ACRL's many accomplishments during the 2014 fiscal year across the three strategic goal areas highlighted in the Plan for Excellence - the value of academic libraries, student learning, and the research and scholarly environment — along with the association's enabling programs and services.

\section{The Value of Academic Libraries}

ACRL made significant progress on the association's goal of assisting academic libraries in demonstrating alignment with, and impact on, institutional outcomes this year.

The association provides support and training to ACRL liaisons to other higher education organizations and disciplinary societies so that they are prepared to talk about the value of academic libraries in those contexts. In order to further influence national conversations and activities, ACRL members and staff have presented about the value of academic libraries initiative at several conferences, including the Library Assessment Conference, Illinois Library Association, International Federation of Library Associations, Professional and Organization Development Network in Higher Education, and WASC Academic Resource Conference. 
ACRL's Standards for Libraries in Higher Education continue to be an active part of the Value initiative. The association licensed and offered five full-day workshops on implementing the standards over the past year. More than 260 print copies of the revised Standards for Libraries in Higher Education were distributed this year and the online version was visited nearly 17,000 times.

Members of the Value of Academic Libraries Committee continue to regularly highlight significant research and project reports on the VAL blog at www.acrl.ala.org/value/ and the Valueography at http://acrl.ala.org/valueography/.

\section{Assessment in Action Program}

In September 2012, ACRL was awarded a National Leadership Demonstration Grant of $\$ 249,330$ by the Institute of Museum and Library Services for the program "Assessment in Action: Academic Libraries and Student Success" (AiA). Part of ACRL's Value of Academic Libraries initiative, AiA is being undertaken in partnership with the Association for

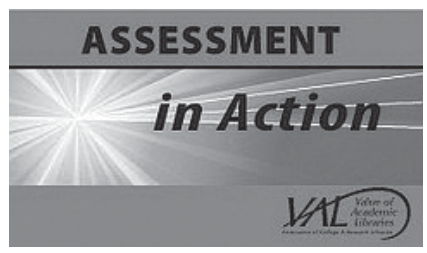
Institutional Research and the Association of Public and Land-grant Universities (APLU). The grant supports the design, implementation, and evaluation of a program to strengthen the competencies of librarians in campus leadership and data-informed advocacy.

Seventy-three institutional teams were selected from a pool of 98 applicants to participate in the second year of the program. The teams, representing all types of institutions, come from 34 states and 1 Canadian province. These teams join the 75 institutions that participated in the first year of the program and are just completing their 14 month experience. For a list of institutions from both years of the program, visit the AiA program webpage at www.ala.org/acrl/AiA.

The AiA program employs a blended learning environment and a peer-to-peer network over the course of the 14-month long program, which runs from April 2014 to June 2015. The librarians will participate as cohort members in a one-year professional development program that includes team-based activities carried out on their campuses. An important component of the AiA program is establishing a learning community where librarian team leaders have the freedom to connect, risk, and learn together.

\section{ACRLMetrics}

To assist with evaluating library performance, ACRLMetrics added the 2012 ACRL survey data as well as selected IPEDS elements. This online product provides unprecedented access to the annual ACRL Academic Library Trends and Statistics Survey data as well as the biennial National Center for Education Statistics (NCES) Academic Library Survey data from 2000 to 2012. ACRLMetrics facilitates performance analysis and decision-making with peer benchmarking and customized reports for use in presentations, grant applications, self-studies, and strategic planning. 


\section{Yeall in Review}

\section{Student Learning}

The following activities are examples of ways ACRL moved towards achieving the association's goal of assisting librarians in transforming student learning, pedagogy, and instructional practices through creative and innovative collaborations.

The ACRL Information Literacy Competency Standards for Higher Education continue to be widely cited as a benchmark in information literacy instruction. This year the standards were cited in numerous books, journal articles, and blogs along with ACRL's own publications. More than 325 print copies of the standards were distributed this year, and the online version was visited more than 131,000 times.

The ACRL Board of Directors appointed a task force in 2013 to update the Information Literacy Competency Standards for Higher Education, adopted by the association in 2000, so that they reflect the current thinking on the creation and dissemination of knowledge, the changing global higher education and learning environment, the shift from information literacy to information fluency, and the expanding definition of information literacy to include multiple literacies. In fall 2013, the task force held three online open forums to inform constituents about the composition of the group, the direction it is taking in revising the standards, and for participants to share their input, reactions, and questions.

To better equip students to navigate, understand, and contribute in this dynamic information ecosystem, the task force determined that a move from the traditional standards model to a framework was needed to allow for more creative and integrated information literacy learning outcomes. The new framework seeks to address the interconnected nature of the abilities, practices, and dispositions of the student, moving away from the hierarchical and formulaic approach of the current standards. An initial draft of the new Framework for Information Literacy for Higher Education was released in two parts during winter and spring of 2014, with comments collected through the task force website and two additional online forums. A revised draft of the Framework was released in June 2014, with hearings held at the 2014 ALA Annual Conference in Las Vegas. A final draft of the Framework, incorporating online and in-person feedback on the June draft, is expected to be released in fall 2014.

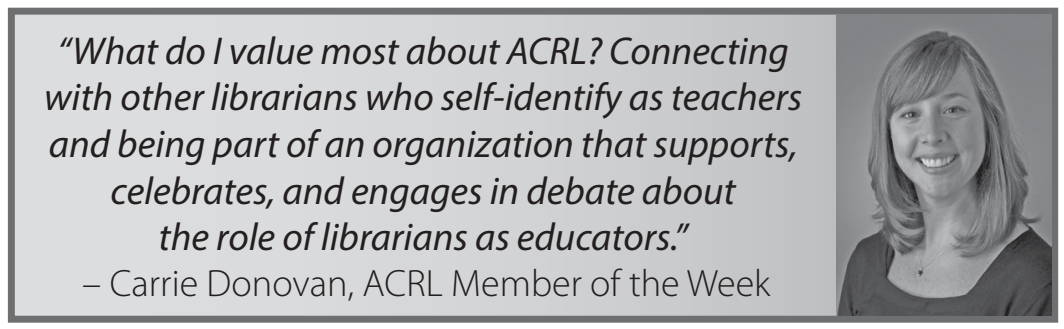

ACRL's discipline-specific information literacy standards act as a guide for providing information literacy instruction in a wide range of content areas. The association will be looking to revise these standards following the anticipated review of the draft Framework by the Board of Directors in early 2015. 


\section{Yearl in Review}

A variety of e-learning courses and webcasts, along with programs and preconference sessions at the ALA Midwinter Meeting and ALA Annual Conference, provided additional opportunities for librarians to gain additional skills in these important areas.

\section{Information Literacy Immersion Program}

ACRL endeavors to improve members' ability to teach and assess lifelong learning skills. To help librarians and institutions develop and implement information literacy programs on their campuses, the ACRL Immersion "Classic" Program was offered from July 20-25, 2014, at Champlain College in Burlington, Vermont. The program provided two tracks of intensive training and education for 87 attendees. The Teacher Track focused on individual development for librarians interested in enhancing or extending their individual instruction skills, while the Program Track focused on developing, integrating, or managing campus-wide and programmatic information literacy programs.

Forty-six attendees participated in the Assessment and Intentional Teacher Tracks, held November 24-28, 2013, in Nashville. The Assessment Track provided attendees with an understanding of assessment and information on how to use assessment as a tool to guide evidence-based classroom, curriculum, and program development. The Intentional Teacher Track offered a mixture of structured and co-constructed learning segments, such as peer discussions, individual reading and reflection times, and participant-led communities of practice to help attendees become more self-aware and self-directed as teachers.

The Immersion Program added four new faculty members this year. The new faculty are Anne Barnhart (University of West Georgia), Daisy Benson (University of Vermont), Melissa BowlesTerry (University of Nevada-Las Vegas), and Steven Hoover (Syracuse University).

\section{Professional Development}

Five e-learning seminars and webcasts provided opportunities to learn more about information literacy and student learning-related topics. Topics of the e-learning opportunities included Creating Accessible Video Tutorials, Cultivating Creators: Copyright in the Information Literacy Classroom, Embedded Librarianship — The State of the Art, On the Road to Information Literacy Success: Putting Students in the "Driver's" Seat, and You're Doing it Wrong: Ten Rules to Break to Create Awesome Tutorials.

Several ACRL sections additionally sponsored information literacy-related programs at the 2014 ALA Annual Conference. See page 623 for a full list of program topics.

ACRL continues to publish a variety of information literacy and learning titles. The Embedded Librarian's Cookbook, edited by Kaijsa Calkins and Cassandra Kvenild; Interactive Open Educational Resources: A Guide to Finding, Choosing, and Using What's Out There to Transform College Teaching, by John D. Shank (copublished with Josey Bass); Snapshots of Reality: A Practical Guide to Formative Assessment in Library Instruction, edited by Elizabeth Leonard and Erin McCaffrey; and Virtually Embedded: The Librarian in an Online Environment, edited by Mary Snyder Broussard, Rachel Hickoff-Cresko, and Jessica Urick Oberlin, were published this year. 


\section{Yeall in Review}

\section{Intersections of Scholarly Communication and Information Literacy}

The ACRL Intersections of Scholarly Communication and Information Literacy Task Force continued its work in promoting the connections between these two areas of the Plan for Excellence by proposing and delivering sustainable professional development opportunities building on the ideas and recommendations in the Intersections white paper this year. Task force members published an article in $C \& R L$ News detailing current developments in the two areas and further highlighted their work through a presentation at CNI.

\section{Research and Scholarly Environment}

ACRL's research and scholarly activities programs actively promote the transition to a more open system of scholarship. ACRL's scholarly communication program actively promotes a commitment to the greater good through the transition to a more open system of scholarship. On March 17, 2014, the association joined the Open Access Working Group in sending a letter to the Committee on Science, Space and Technology of the U.S. House of Representatives expressing strong opposition to the language contained in Section 303 of the recently introduced Frontiers in Innovation, Research, Science, and Technology Act of 2014 (FIRST Act). This action followed a 2013 letter expressing opposition to a 2013 version of the FIRST Act. One provision of the bill would undercut federal agencies' ability to effectively implement the widely supported White House Office of Science and Technology Policy Directive on Public Access to the Results of Federally Funded Research, undermine the public access program pioneered by the National Institutes of Health, and put the United States at a severe disadvantage among our global competitors. We encouraged ACRL members to contact their members of Congress to express opposition to the legislation.

The association continued its objective to increase the ways it is an advocate and model for open dissemination and evaluation practices this year through the transition of our research journal, College \& Research Libraries, to an online only, open access publication. The November 2013 issue was the final print issue of the journal. This shift in publication model is the result of thoughtful study undertaken with input from a survey of the ACRL membership by the Board of Directors, Budget $\&$ Finance Committee, $C \& R L$ Editorial Board, Publications Coordinating Committee, and other stakeholder groups to balance the ways readers prefer to engage with ACRL publications with the financial realities of the changing scholarly publishing landscape. The $C \& R L$ Editorial Board continues to explore new models of scholarly communication practice through its social media program and the addition of new features such as Digital Object Identifiers to the journal website. The association was invited to present on its open access initiatives at meetings of the Council for Learned Societies and the American Historical Association during the fiscal year.

The ACRL Research and Scholarly Environment Committee (ReSEC) selected five sites from 14 applications to host the workshop "Scholarly Communication: From Understanding to Engagement" as road show events this spring and summer. The institutions selected to host the 2014 road shows were Michigan State University, East Lansing, Michigan (April 11); Baylor University, Waco, Texas (May 2); Council of Atlantic University Libraries/Conseil des bibliothèques universitaires de 1'Atlantique, Fredericton, New Brunswick (May 9); California State University-San Marcos, California (June 6); and 


\section{Yearl in Review}

University of Mississippi, Oxford, Miss. (July 18). The workshop focuses on access, emerging opportunities, intellectual property, and engagement. When the 2014 workshops are complete, the road show will have visited 21 different states, the District of Columbia, 1 U.S. territory, and 3 Canadian provinces. The 33 workshops offered over the program's five years will have reached more than 2,000 participants from over 550 institutions. ACRL also makes the workshop available to additional interested institutions.

ACRL held a two day invitational Data Management Forum at Drexel University prior to the 2014 ALA Midwinter Meeting in collaboration with Drexel Dean of Libraries Danuta Nitecki. The first day of the forum involved discussion with seven Drexel faculty members regarding their data management needs, while the second was a meeting of librarians working in the area of data curation and management, ReSEC Committee members, and Board of Directors members to consider ACRL's potential role in this growing area. Two additional e-learning events, the online course "What You Need to Know about Writing Data Management Plans" and a webcast providing "An Introduction to Data Management Plans," on data management were presented this year.

A paper on managing change using data management was presented at IFLA's Knowledge Management Standing Committee's 2014 Satellite Conference.

The ACRL Scholarly Communication Discussion Group, Scholcomm discussion list, and the ACRL/SPARC Forum on Emerging Issues in Scholarly Communication continue to be important venues for strengthening the association's role in supporting new models of scholarly communication. Regular articles on scholarly communication issues and trends in $C \& R L N e w s$ play an important role in disseminating a body of knowledge for the field.

\section{Enabling Programs and Services}

In addition to the three Plan for Excellence goal areas, ACRL serves its members, along with the academic and research library community, through a wide variety of programs and services. Highlights of the regularly recurring operations relevant to the ability of ACRL to lead academic and research librarians and libraries in advancing learning and scholarship are reported below.

\section{Member Engagement}

ACRL's membership activities build on retaining core membership while recruiting from new and diverse communities. As of August 31, 2014, ACRL had 11,010 members, a decrease of $7.82 \%$ (934 fewer members) than FY13 $(11,944)$. There are currently 10,269 personal members, 721 organizational members, and 20 corporate members.

ACRL continues to explore new models for member connections. The ACRL 101 program at the ALA Annual Conference educates members and potential members on the wide range of ACRL activities and opportunities for participation. For the third year, the association held a virtual orientation session for incoming leaders. A number of ACRL committees, interest groups, sections, and the Board of Directors are working virtually and taking advantage of ALA Connect and other virtual meeting systems to keep the work of the association moving forward year round. 


\section{Yearl in Review}

As of August 2014, 6,197 individuals "like" the official ACRLFacebook page (www.facebook.com /ala.acrl) and 11,096 people follow the association on Twitter (https://twitter.com/ALA_ACRL). Many ACRL sections, including AFAS, Arts, CLS, IS, LES, LPSS, and WGSS, have Facebook pages or groups for their members and other interested parties. ACRL's scholarly research journal College \& Research Libraries also maintains Facebook and Twitter presences. These online presences provide avenues for information dissemination and connection with, and between, members. The ACRL Pinterest site (www.pinterest.com/acrlala/) provides a visual picture of the association, including images of award winners, members of the week, ACRL publication covers, and more. As of August 2014, 344 people follow ACRL's Pinterest presence.

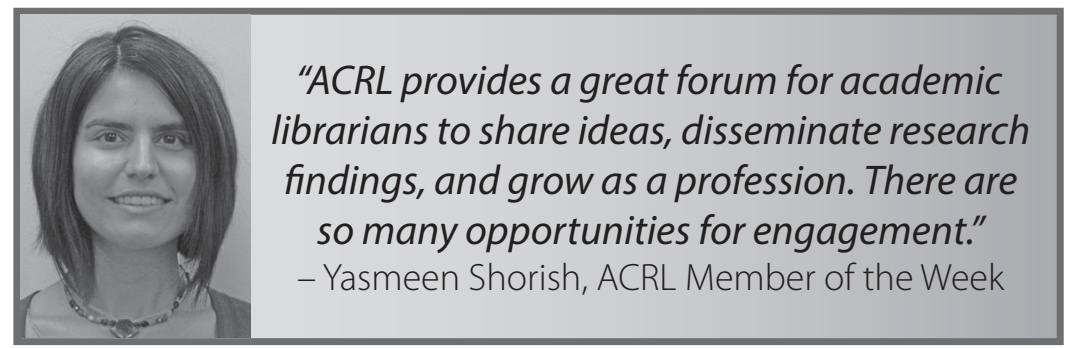

The ACRL Insider blog (www.acrl.ala.org/acrlinsider/) continues to keep readers current and informed on the activities, services, and programs of the association and features weekly profiles of ACRL members. The biweekly ACRL Update e-newsletter, along with publications and e-Learning course announcements, continue to be distributed to more than 13,000 subscribers to increase awareness of ACRL activities.

ACRL continues to sponsor participants in the ALA Emerging Leaders program. This year's five ACRL-sponsored emerging leaders were Kai Alexis Smith (sponsored by ACRL), Kate Leuschke Blinn (sponsored by CLS), Jonathan DaSo (sponsored by LES, SEES, and WESS), Margaret Phillips (sponsored by STS), and Nataly Blas (sponsored by ULS).

As part of its commitment to furthering diversity in librarianship, the association is supporting Lucero Gonzalez as its 2014-15 Spectrum Scholar. Gonzalez attends the University of Illinois at Urbana-Champaign. Since 1999, ACRL has provided more than $\$ 96,000$ in direct support to the Spectrum Scholarship Program and offered complimentary ACRL membership to all Spectrum Scholars.

In addition, ACRL assists scholars through mentoring and conference assistance. The ACRL Dr. E. J. Josey Spectrum Mentor Committee supports Spectrum Scholars with an interest in academic libraries by pairing them with a trained mentor from an academic library. The committee has paired more than 100 Spectrum Scholars with mentors since 2003 and is working to pair interested current scholars and scholars from the incoming Spectrum class. The committee developed new assessment tools to gather and measure feedback from mentors and mentees about the use and effectiveness of the mentoring program; these tools were implemented in FY14, and will be refined as future cohorts use and review the data gathered. ACRL also provides four scholarship awards that support travel for the attendance of Spectrum Scholars at ACRL conferences. 
ACRL Communities of Practice Membership Statistics

\begin{tabular}{|c|c|c|c|c|c|}
\hline $\begin{array}{l}\text { ACRL } \\
\text { Sections }\end{array}$ & Personal & $\begin{array}{l}\text { Organizational } \\
\text { and Corporate }\end{array}$ & $\begin{array}{c}\text { August } 2014 \\
\text { total }\end{array}$ & $\begin{array}{c}\text { August } 2013 \\
\text { total }\end{array}$ & Change \\
\hline ACRL & 10,269 & 741 & 11,010 & 11,944 & $-7.82 \%$ \\
\hline AAMES & 256 & 33 & 289 & 309 & $-6.47 \%$ \\
\hline AFAS & 185 & 9 & 194 & 219 & $-11.42 \%$ \\
\hline ANSS & 392 & 32 & 424 & 471 & $-9.98 \%$ \\
\hline Arts & 703 & 44 & 747 & 813 & $-8.12 \%$ \\
\hline CJCLS & 1,112 & 124 & 1,236 & 1,357 & $-8.92 \%$ \\
\hline CLS & 2,319 & 157 & 2,476 & 2,748 & $-9.90 \%$ \\
\hline DLS & 1,413 & 58 & 1,471 & 1,581 & $-6.96 \%$ \\
\hline EBSS & 699 & 80 & 779 & 863 & $-9.73 \%$ \\
\hline IS & 3,773 & 216 & 3,989 & 4,322 & $-7.70 \%$ \\
\hline LES & 485 & 11 & 496 & 552 & $-10.14 \%$ \\
\hline LPSS & 373 & 39 & 412 & 471 & $-12.53 \%$ \\
\hline RBMS & 1,508 & 77 & 1,585 & 1,697 & $-6.60 \%$ \\
\hline SEES & 133 & 19 & 152 & 185 & $-17.84 \%$ \\
\hline STS & 1,139 & 90 & 1,229 & 1,334 & $-7.87 \%$ \\
\hline ULS & 3,862 & 157 & 4,019 & 4,475 & $-10.19 \%$ \\
\hline WESS & 398 & 23 & 421 & 441 & $-4.54 \%$ \\
\hline WGSS & 417 & 20 & 437 & 399 & $+9.52 \%$ \\
\hline
\end{tabular}

Total Personal Section Affiliations 20,356

\begin{tabular}{|c|c|c|c|c|c|}
\hline $\begin{array}{l}\text { Interest } \\
\text { Groups }\end{array}$ & Personal & $\begin{array}{l}\text { Organizational } \\
\text { and Corporate }\end{array}$ & $\begin{array}{c}\text { August } 2014 \\
\text { total }\end{array}$ & $\begin{array}{c}\text { August } 2013 \\
\text { total }\end{array}$ & Change \\
\hline $\begin{array}{l}\text { Academic Library } \\
\text { Services to Internation: }\end{array}$ & $\begin{array}{l}354 \\
\text { nal Student }\end{array}$ & 1 & 355 & 382 & $-7.07 \%$ \\
\hline Digital Curation & 931 & 4 & 935 & 892 & $+4.82 \%$ \\
\hline Health Sciences & 491 & 3 & 494 & 523 & $-5.54 \%$ \\
\hline Image Resources & 261 & 3 & 264 & 304 & $-13.16 \%$ \\
\hline $\begin{array}{l}\text { Librarianship in } \\
\text { For-Profit Institutions }\end{array}$ & 153 & 1 & 154 & 122 & $+26.23 \%$ \\
\hline \multicolumn{6}{|c|}{ Science (LIS) Education } \\
\hline $\begin{array}{l}\text { Numeric \& } \\
\text { Geospatial Data }\end{array}$ & 243 & 1 & 244 & 236 & $+3.39 \%$ \\
\hline Residency & 59 & $\mathbf{0}$ & 59 & 59 & $0.00 \%$ \\
\hline Technical Services & 328 & 3 & 331 & N/A & N/A \\
\hline Universal Accessibility & 193 & $\mathbf{0}$ & 193 & 187 & $+3.21 \%$ \\
\hline Virtual Worlds & 130 & 0 & 130 & 168 & $-22.62 \%$ \\
\hline
\end{tabular}

Total Personal IG

Affiliations

Note: The Digital Humanities Interest Group and the Library Marketing and Outreach Interest Group were added as dues products September 1, 2014. Membership figures will be available for FY15. 


\section{leall in Review}

\section{Communities of Practice}

Sections

ACRL provides special connections for members, both virtual and personal. ACRL sections offer 17 vibrant and dynamic communities that nurture individual development and foster a deeper connection to the profession. Sections also hosted dozens of special events (socials, dinners, receptions) at the ALA Midwinter Meeting and ALA Annual Conference to create community among new and continuing members.

\section{Interest Groups}

As of August 2014, the 11 ACRL interest groups-Academic Library Services to International Students, Digital Curation, Health Sciences, Image Resources, Librarianship in For-Profit Educational Institutions, Library and Information Science (LIS) Education, Numeric and Geospatial Data Services in Academic Libraries, Residency Programs, Technical Services, Universal Accessibility, and Virtual Worlds have attracted 3,387 members, with an average membership of 307. The Digital Curation Interest Group currently has the most members (931). The newest interest groups, Digital Badges, Digital Humanities, and Library Marketing and Outreach, opened for affiliation September 1, 2014 , bringing the total number of interest groups to 14. Approved by the ACRL membership in the 2008 ALA/ACRL election, interest groups provide a way to easily create a "home" within ACRL for topics and issues that are currently underrepresented in the organization.

\section{Discussion Groups}

The ACRL Board of Directors approved the dissolution of the Marketing Discussion Group with the development of the Library Marketing and Outreach Interest Group, bringing the total number of ACRL discussion groups to 22 .

\section{Awards}

Through its awards program, which recognizes the achievements of academic and research librarians and libraries, ACRL provides a platform for librarians to bring notice of their work to their broader communities. Since 1923, the ACRL Awards Program has recognized and honored the professional contributions and achievements of academic libraries and librarians. This special recognition by ACRL enhances the sense of personal growth and accomplishment of members, provides membership with role models, and strengthens the image of ACRL membership in the eyes of employers, leadership, and the academic community as a whole.

In 2014, 30 outstanding individuals and institutions received ACRL awards recognizing their accomplishments. ACRL's top honor, the Academic/Research Librarian of the Year Award, was presented to Tim Bucknall, assistant dean of libraries and head of electronic resources and information technologies at the University of North Carolina-Greensboro. Bucknall was cited for his work in building consortia, leveraging e-resources, and improving use of information technology are important contributions to the profession.

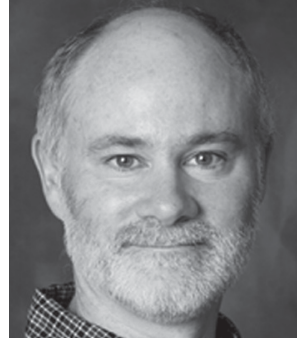

Tim Bucknall, 2014 Academic/Research Librarian of the Year 


\section{ACRL AWARD WINNERS 2014 \\ Division Award Winners}

Academic/Research Librarian of the Year Award (Donor: YBP Library Services) Tim Bucknall, Assistant Dean of Libraries and Head of Electronic Resources and Information Technologies, University of North Carolina-Greensboro

- Excellence in Academic Libraries

(Donor: YBP Library Services)

University: Cal Poly State University, San Luis Obispo, California;

College: Lafayette College, Easton, Pennsylvania;

Community College: Illinois Central College, East Peoria, Illinois

- Hugh C. Atkinson Memorial Award

(ACRL, ALCTS, LLAMA, LITA) Anne R. Kenney, Cornell University

\section{Section Award Winners}

- CJCLS Library Program Achievement Award (Donor: EBSCO Information Services) Parkland College Library and Center for Excellence in Teaching and Learning staffs

CJCLS Library Resources Leadership Award (Donor: EBSCO Information Services) David M. Rodriguez, Maricopa Community College District and Glendale Community College

- CLS ProQuest Innovation in College Librarianship Award (Donor: ProQuest) Tish Hayes, Terra B. Jacobson, and Troy A. Swanson, all of the Moraine Valley Community College

- DLS Routledge Distance Learning Librarianship Conference Sponsorship Award (Donor: Routledge/Taylor \& Francis Group) Frederick Stielow, American Public University System

- EBSS Distinguished Education and Behavioral Sciences Librarian Award (Donor: John Wiley \& Sons, Inc.) Stephanie Davis-Kahl, Illinois Wesleyan University

-IS llene F. Rockman Instruction Publication of the Year Award (Donor: Emerald Group Publishing Limited) Wendy Holliday,
Northern Arizona University, and Jim Rogers, Utah State University

- IS Innovation Award (Donor: ProQuest) Meredith Farkas, Amy Hofer, Lisa Molinelli, and Kimberly Willson-St. Clair, all of Portland State University

-IS Miriam Dudley Instruction Librarian Award (Donor: ACRL Instruction Section) Esther Stampfer Grassian, distinguished librarian (emerita), University of CaliforniaLos Angeles

- LPSS Marta Lange/SAGE-CQ Press Award (Donor: SAGE-CQ Press) Brian E. Coutts, Western Kentucky University

aRBMS/Leab Exhibition Catalogue Awards (Donor: Katharine Kyes Leab and Daniel J. Leab Endowment) Category 1 Winner (Expensive): Bruce Peel Collections Library, University of Alberta; CATEgoRY 1 Honorable Mention (Expensive): The American Antiquarian Society; CATEgory 2 WINner (Moderately Expensive): The Cushing Memorial Library and Archives at Texas A\&M University;

\section{Awards continued next page}




\section{Section Award Winners, continued}

nRBMS/Leab Awards, continued: CATEGORY

2 Honorable Mention (Moderately Expensive): The Special Collections Library at Vassar College; Category 3 Winner (IneXPensive): The Lewis Walpole Library at Yale University; CATEgory 4 Winner (BRochures): The Rare Books \& Manuscripts Library of the University of IIlinois at Urbana-Champaign; CATEgory 5 WINNER (ELECTRONIC EXHIBITIONS): The John Carter Brown Library at Brown University
nWESS De Gruyter European Librarianship Study Grant (Donor: de Gruyter Foundation) Marta Mestrovic Deyrup, Seton Hall University

\section{चWGS Achievement in Women's Studies Librarianship Awards}

Career Achievement Laura Micham, Duke University

Significant Achievement Maria T. Accardi, Indiana University Southeast

ACRL continues to present the Excellence in Academic Libraries Award to recognize the staff of a community college, a college, and a university library for exemplary programs that deliver outstanding services and resources to further the educational mission of their institution. This year's recipients were Illinois Central College in the community college category, Lafayette College in the college category, and Cal Poly State University in the university category. The award, sponsored by YBP Library Services, includes a presentation ceremony on the campus of each award-winning library.

\section{Publications}

ACRL's publications program was very active during 2013-14, publishing eight new books, which are listed in the accompanying table. ACRL monographs are available in a variety of e-book formats through the ALA Store and Amazon. E-books of ACRL monograph titles are also available for purchase by libraries through EBSCO.

\section{Serials}

Association members continue to receive College \& Research Libraries News (C\&RL News), ACRL's news magazine and publication of record, as a perquisite of membership. $C \& R L N e w s$ is also available by subscription. As noted earlier in this report, the association's scholarly research journal College \& Research Libraries $(C \& R L)$, is an onlineonly, open access publication. ACRL is proud to make quality research freely available to the higher education community as it models new practices in scholarly communication. RBM: A Journal of Rare Books, Manuscripts, and Cultural Heritage is published in print twice yearly and is available through subscription. ACRL also publishes the Choice suite of products including Choice magazine and Choice Reviews Online.

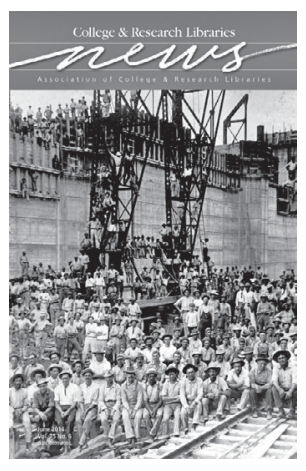

As previous noted, ACRL's official scholarly research journal College \& Research Libraries $(C \& R L)$ adopted an online-only publication model beginning in January 2014. The November 2013 issue was the final print issue of the journal. $C \& R L$ is freely available as an open access online publication. 


\section{ACRL PUBLICATIONS}

\section{ACRL Insider}

- The blog keeping the world current and informed on ACRL activities, services, and programs.

\section{ACRLog: Blogging by and for Academic and Research Librarians}

- The official blog of ACRL features posts on current issues in academic and research librarianship from the blog team.

\section{ACRL TechConnect}

- Blog covering innovative uses of technology in academic and research libraries.

\section{ACRL Value of Academic Libraries}

- Trends and issues related to the ACRL Value of Academic Libraries initiative.

\section{Keeping Up With...}

- Online current awareness publication featuring concise briefs on trends in academic librarianship and higher education. Each edition focuses on a single issue including an introduction to the topic and summaries of key points, including implications for academic libraries.

\section{New Publications in 2013-14}

- 2012 Academic Library Trends and Statistics

- Designing Training (Active Guide \#5)

- The Embedded Librarian's Cookbook

- Interactive Open Educational Resources: A Guide to Finding, Choosing, and Using What's Out There to Transform College Teaching (copublication with Josey Bass)

- The Librarian Stereotype: Deconstructing Perceptions \& Presentations of Information Work

- Putting the User First: 30 Strategies for Transforming Library Services

- Snapshots of Reality: A Practical Guide to Formative Assessment in Library Instruction

- Studying Students: A Second Look

- Virtually Embedded: The Librarian in an Online Environment

\section{ACRL Magazines and Journals}

- College \& Research Libraries - Official scholarly journal of ACRL; six bimonthly issues per year

- College \& Research Libraries News - Official news magazine of ACRL; 11 issues per year (July/August combined)

- RBM: A Journal of Rare Books, Manuscripts, and Cultural Heritage-A journal of theory and practice covering all aspects of special collections librarianship; two issues per year

\section{CHOICE Publications}

- Choice magazine-Book review journal of ACRL, includes special editorial features and reviews; published monthly

- Choice Reviews on Cards - Choice reviews, and just the reviews, on cards; published monthly

- Choice Reviews Online Version 3.0 - The current Web version of Choice magazine; provides 24/7 access to all of Choice's editorial content, including all reviews published since September 1988 plus a customizable monthly e-mail bulletin (www.cro3.org). 


\section{Yearl in Review}

Mark Shelton of Harvard University was appointed to the post of book review editor of $C \& R L$ this year. Currently head of collection development at Harvard's Gutman Library, Shelton brings more than 17 years of academic library leadership experience to the position, including extensive knowledge of collection development, acquisitions, and licensing. Shelton has written numerous book reviews for $C \& R L$ and Collection Building, in addition to serving as a library advisory board member for a variety of publishers.

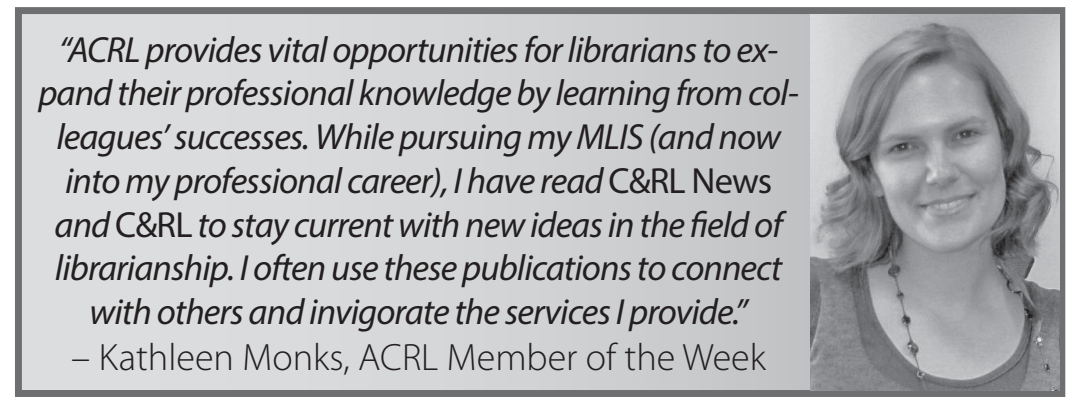

$C \& R L$ launched Facebook and Twitter presences in September 2013 to increase reader engagement with the journal. Both sites are home to updates on pre-print and current articles, book reviews, highlights of past articles from the journal's nearly 75-year history, and exclusive content from $C \& R L$ editors and researchers. As part of its social media program, the journal hosted three online fora this year. Each forum highlighted a new $C \& R L$ study with a free, live, expert panel comprised of the study's authors and additional subject experts. "Academic Mentoring: A Discussion of Benefits, Expectations, and Support," held in December 2013, featured a live online panel discussion of the benefits of mentoring for academic libraries of all sizes. "Creating a Culture of Assessment in Academic Libraries," held in April 2014, featured a live panel conversation on creating and maintaining a culture of assessment at your library and factors associated with it. "Mapping Library Contributions to Campus Internationalization," held in July 2014, focused on library internationalization efforts.

Jennifer K. Sheehan, exhibits manager at The Grolier Club, was named the next editor of $R B M$ : A Journal of Rare Books, Manuscripts, and Cultural Heritage (RBM) in April 2014. Sheehan was previously a member of the $R B M$ editorial board and brings in-depth knowledge of the world of rare books and manuscripts to the bi-annual publication. Prior to joining The Grolier Club in 2013, Sheehan served as curator of rare books at the University of North Texas, where she also teaches as an adjunct faculty member in the Department of Library and Information Sciences.

\section{CHOICE}

In March of this year, Choice celebrated its 50th anniversary of continuous publication, a rare event in academic publishing, particularly in these times of rapid technological change. During its 51st year Choice will publish more than 7,000 reviews, bringing the total number of records in its database to 185,000 , all of which are available to subscribers to Choice Reviews Online (www.cro3.org), now released in its third edition on the HighWire Press platform. This past January also saw the 49th publication of our prestigious "Outstanding Academic Titles" list. This year's list singled out 663 of the most noteworthy titles of 2013, representing selections from 54 academic disciplines, for exceptional praise. 
Fiscal 2014 was a year of significant staffing changes for Choice, with two retirements, two editorial appointments, and the hiring of a marketing manager. Tom Radko, formerly Choice operations manager, was promoted to the position of editorial director following the retirement of Fran Graf after 30 years of service to Choice. Under Radko's leadership Choice is planning significant new editorial features designed to address important topics in academic librarianship. Succeeding Radko as operations manager is Rachel Hendrick, who joined the staff in May, just in time for the launch of a new back-end publishing system, Choice Connect. Hendrick comes to Choice from Sotheby's, where she project managed the final production of Sotheby's digital iPad catalog.

Laura Mullen, Choice's new marketing manager, worked as an independent marketing consultant following her tenure at ABC-CLIO/Greenwood, where she was responsible for a $\$ 1.5 \mathrm{MM}$ publicity budget. Mullen spent much of her first ten months at Choice developing a significant market research program and spearheading the creation of Choice360.org, the new Choice marketing website designed to provide a single point of information about the entire range of Choice services and publications.

The 2013-14 fiscal year also marked the formal launch of the ACRL-Choice webinar program, the purpose of which is to connect the library community with publishers and other content providers around topics of common interest. Some of the themes explored in the ten broadcasts staged during our first webinar season included open access, ebook publishing, language acquisition, and reference works. Registration is currently running at more than 500 participants per session, indicating strong interest in this new program, which in turn has led sponsors to book 26 additional webinars for the 2014-15 year.

Resources for College Libraries (RCL), a copublishing venture with Bowker, continues to be enhanced with new edition updates and annual revisions and finished the fiscal year with strong subscription sales. The combined $R C L$ and " $R C L$ Career Resources" database now contains over 85,800 titles. $R C L$ is now also embedded in Bowker's new Intota collection assessment tool, widening both the reach and the utility of the $R C L$ database.

Finally, Choice's social media consultant, Karin Holmgren, significantly expanded Choice's social media presence in FY14. As of early September of this year, Choice's Facebook following had once again doubled year over year, to 8,500 friends, who now have access to an expanded portfolio of Choice content and information on the site.

\section{Reports, White Papers, Online Publications}

ACRL released "Environmental Scan of OERs, MOOCs, and Libraries: What Effectiveness and Sustainability Means for Libraries' Impact on Open Education," a research report by Carmen Kazakoff-Lane, in March 2014. Kazakoff-Lane (extension librarian at the Brandon University John E. Robbins Library in Brandon, Manitoba, Canada) introduces and provides background on the open educational resources (OER) and massive open online course (MOOC) movements and investigates the effectiveness and challenges to sustainability of each.

The ACRL Research Planning and Review Committee published its bi-annual "Top trends in academic libraries: A review of the trends and issues affecting academic libraries in 


\section{Yearl in Review}

higher education" in the June 2014 issue of $C \& R L$ News. This year, after numerous discussions and literature reviews, the committee decided upon a unifying theme for current trends: deeper collaboration. The committee focused on the following large categories within higher education: data, device neutral digital services, evolving openness in higher education, student success initiatives, competency-based learning, altmetrics, and digital humanities. The report is freely available at http://crln.acrl.org/content/75/6/294.full.

“Keeping Up With...", ACRL's online current awareness publication series, continued issuing concise briefs on trends in academic librarianship and higher education. Each edition focuses on a single issue, including an introduction to the topic and summaries of key points, including implications for academic libraries. The series' offerings this year included information on digital badges for instruction, visual literacy, altmetrics, augmented reality, MOOCs, digital writing, financial literacy, patron driven acquisitions, and net neutrality. "Keeping Up With..." is available on the ACRL website at www.ala.org/acrl/publications/keeping_up_with.

\section{Blogs/Podcasts/Social Media}

ACRL continued to leverage social media and other new technologies to deliver content over the past year. The ACRL Insider blog provides daily updates of association activities. ACRLog provides ideas, commentary, and reflection on the professional issues of the day. The ACRL TechConnect blog covers innovative uses of technology in academic and research libraries. The Value of Academic Libraries blog features news on the association's Value of Academic Libraries initiative along with essays from members of the Value of Academic Libraries Committee. Several ACRL groups also manage content blogs focused on their specialties. As noted in the member engagement section, ACRL social media presences on Facebook, Twitter, and Pinterest provide news and avenues for engagement with the association.

ALA JobLIST (http://joblist.ala.org), the online career center operated since 2006 by $C \& R L$ News in partnership with American Libraries and ALA's Office for Human Resource

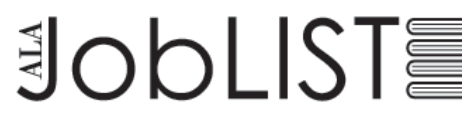
Development and Recruitment (HRDR), offers services for both job seekers and employers. The site published more job ads in FY14 than in any year since FY08, many of the ads announcing multiple available positions. JobLIST also reaches thousands of followers with links to helpful career and job search information on Twitter, Facebook, Google+, and LinkedIn. Face-to-face services are made available through the ALA JobLIST Placement Center, operated by HRDR at major ALA and ACRL conferences, which has also offered occasional webinars and other virtual development opportunities throughout the year.

ACRLog (http://acrlog.org) is now heading into its eighth year of operation. The blog, which discusses the issues of the day in academic and research librarianship, featured 53 posts from the blog team and assorted guests in FY14.

The ACRL Insider blog (http://acrl.ala.org/acrlinsider) continued to distribute information on publications, events, conferences, and other association activities to the membership and beyond. There were 225 posts to ACRL Insider during the fiscal year. The Member of the Week feature continues to highlight the diversity of the association and remains one of the most popular features of the blog. 
The ACRL TechConnect blog (http://acrl.ala.org/techconnect) is a moderated blog covering innovative projects, emerging tech tools, computer programming, usability, design, and more. There were 36 posts to ACRL TechConnect during the fiscal year.

The ACRL Value of Academic Libraries blog (http://acrl.ala.org/value) covers trends and issues related to the association's Value of Academic Libraries initiative. There were 24 posts to the blog during the fiscal year.

\section{Standards and Guidelines}

The development of standards and guidelines for all areas of academic and research librarianship is a core service of ACRL. These standards and guidelines are a key ACRL contribution to the profession. New Information Literacy Competency Standards for Nursing were approved this year, and the Guidelines for University Library Services to Undergraduate Students were revised.

As noted in the Student Learning section of this report, a Board of Directors-appointed Information Literacy Competency Standards for Higher Education Task Force is continuing work on an extensive revision of the standards.

\section{Education}

ACRL continues to offer a wide range of professional development programs and events to meet the needs of today's academic and research librarians.

\section{ACRL Conference}

The ACRL 2015 conference will be held March 25-28, 2015, in Portland, Oregon. The conference will feature keynote speaker writer G. Willow Wilson, RadioLab co-host Jad Abumrad, and academic/political activist Lawrence Lessig. Proposals for contributed papers,

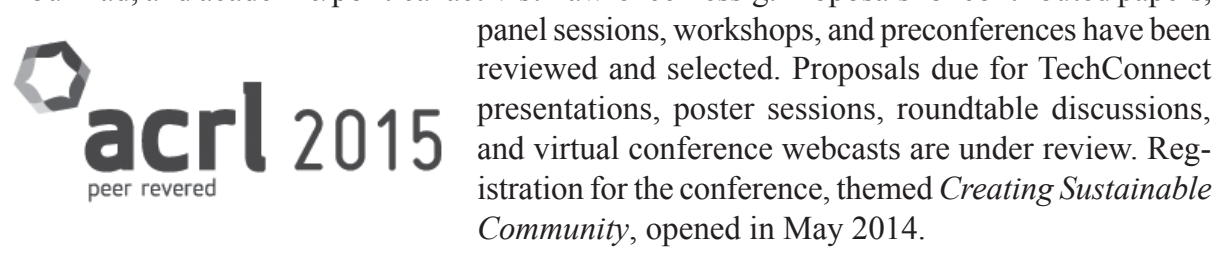

As part of ACRL's 75th Anniversary celebration, the association launched a fundraising campaign seeking to raise $\$ 50,000$ by December 31,2014 , to provide 75 scholarships for members in a variety of categories to attend ACRL 2015. More information on the 75th Anniversary is available earlier in this report.

\section{ACRL@ALA Annual Conference}

ACRL preconference sessions at the 2014 ALA Annual Conference in Las Vegas provided information on circulating iPads in the library and strategies to cultivate a habit of scholarship. The ACRL President's Program brought together leaders in financial advising and higher education, including Ferris State University President David Eisler and Washington Post columnist Michelle Singletary, to discuss the importance of financial education on college campuses and some ways in which college students especially can learn how to more effectively manage their finances. 


\section{Yeatr in Review}

ACRL sponsored an additional 19 section, committee, and individual programs in Las Vegas on topics such as information literacy, the impact of neuroscience on architecture and design, surveillance, residency programs, digital humanities, perceptions of academic librarians, collaborative publishing, and open access. A list of programs is available in the table on page 623 .

\section{5th RBMS Preconference}

The 55th Annual RBMS Preconference, Retrofit: Exploring Space, Place and the Artifact in Special Collections, was held June 24-27 in Las Vegas. This year's event featured three plenaries, nine seminars, ten papers, nine discussion sessions, and two workshops, along with ten posters, an open house at the UNLV Special Collections \& Lied Library, and tours of the Clark County Museum, the International Museum and Library of the Conjuring Arts, the National Atomic Testing Museum, and the Neon Museum. Highlights included talks on digital humanities, preservation, instruction with physical and digital materials, the future of special collections, diversity, library spaces, crowdsourcing, and digital collections.

\section{Leadership Institutes}

The association continued to partner with the Harvard Graduate School of Education to offer the ACRL Harvard Leadership Institute for Academic Librarians. One hundred and five individuals participated in this year's program, held in Cambridge, Massachusetts, July 28-August 1, 2014. The program is designed for academic librarians with significant administrative responsibility, such as library directors, their associates, and direct reports.

ACRL again collaborated with other higher education associations to offer the Women's Leadership Institute, held December 3-6, 2013, in Amelia Island, Florida. The Women's Leadership Institute is an experience that provides professional development opportunities on issues that affect women within the higher education community. The program has the added benefit of bringing together women from administrative and student affairs functions across institutions of higher education.

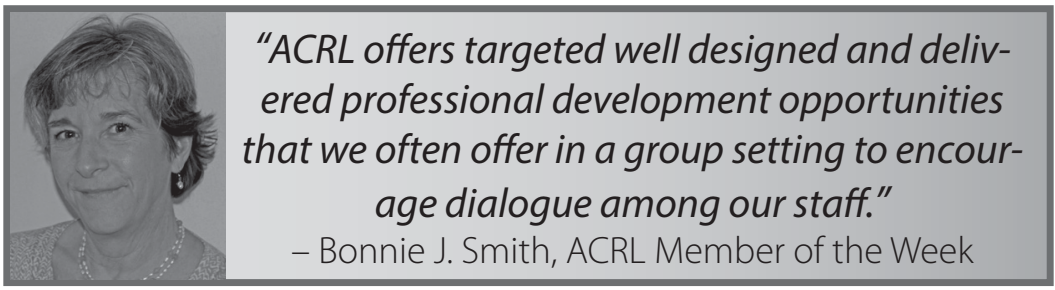

ACRL Springboard Event

ACRL offered its fourth annual Springboard Event on September 30, 2013. 2013-14 ACRL President Trevor A. Dawes led a discussion on the need for academic libraries to get involved in financial literacy education, which highlighted current successful efforts from across the country including a presentation from Shana Gass of Towson University, on how academic libraries can participate in Money Smart Week @ your library. Chris LeBeau, past chair of the Business Reference and Services Section (BRASS) of the Reference and User Services Association (RUSA), provided information about the new RUSA-BRASS IMLS grant to 
develop guidelines for financial literacy programming as well as some current resources for financial literacy education. The ACRL Springboard Event is a live, interactive webinar offered free of charge to all ACRL members. This year's webinar was offered in partnership with RUSA-BRASS and the ALA Chapter Relations Office.

\section{ACRL promotes continuous learning through preconferences, workshops, and e-learning}

\section{Preconferences@ALA Annual Conference}

ACRL preconferences continue to provide academic and research librarians with tips, tools, and new ways of thinking. Two preconference were held before the 2014 ALA Annual Conference in Las Vegas:

- iPad, YouPad: Circulating iPad Collections in Academic Libraries

- Maximize Your Professional Time: Strategies to Cultivate a Habit of Scholarship

\section{e-Learning Seminars and Webcasts}

Delivered through Moodle, online seminars provide participants with a dynamic and flexible approach to continuing education. Offerings in 2013-14 were:

- Creating Accessible Video Tutorials

- Customer Service in a Digital Age

- Helping Non-Innovators through Innovation: Managing Change

- On the Road to Information Literacy Success: Putting Students in the "Driver's" Seat

- What You Need to Know about Writing Data Management Plans (offered twice)

The association also expanded its offerings of Webcasts, using an online community hosted by LearningTimes, to deliver real-time, interactive programming over the Web. Offerings in 2013-14 were:

- An Introduction to Data Management Plans

- Cultivating Creators: Copyright in the Information Literacy Classroom

- Developing and Implementing Open Access Policies

- Dress Your Data for Success: Data Visualization Strategies for Library Assessment

- Embedded Librarianship - The State of the Art

- The Evolving World of Course Content as a Service

- Making the Leap to Library Leadership

- New Directions in Art Librarianship

- Out of the Library and Into the Community

- Precision Googling: Techniques to Extract Exactly What You Want from the Largest Search Engine

- Putting the User First

- Riding the Publishing Rollercoaster

- Standards for Libraries in Higher Education (Parts One - Three)

- You're Doing it Wrong: Ten Rules to Break to Create Awesome Tutorials 


\section{Online Learning}

The ACRL e-Learning program offered 21 e-Learning events consisting of 15 webcasts and 6 multiweek courses this year on a variety of topics, such as data management plans, video tutorials, customer service in a digital age, leadership, publishing, and more. More than 550 individuals and 110 groups, representing more than 750 individuals, participated in this year's e-Learning offerings.

\section{Scholarships}

Knowing that professional development is essential to the success of academic and research librarians, we awarded more than $\$ 18,000$ in scholarships this year. Sixty-two scholarships were awarded for the ACRL e-Learning program, Immersion Program, and the 55th RBMS Preconference. Scholarships for the RBMS preconference were funded in part by a generous grant from the Delmas Foundation.

\section{Advocacy}

Continuing the association's focus on advocacy, ACRL aims to increase its communication on major trends and issues in libraries and increase its influence in public policy affecting higher education. ACRL's continued work in the scholarly communication arena, especially as a member of the Library Copyright Alliance (LCA), helped the association to meet these objectives.

\section{Legislative Advocacy}

Public policy issues effecting higher education remain an essential focus of the strategic plan. Each year, the ACRL Government Relations Committee, in consultation with the ACRL Board of Directors and staff, formulates an ACRL Legislative Agenda. Drafted with input from the ACRL Research and Scholarly Environment Committee, along with additional committees, ACRL leaders, and ALA Washington Office, the legislative agenda is prioritized and includes objectives for legislative action at the national level on issues that may affect the welfare of academic and research libraries. The 2014 ACRL Legislative Agenda focuses on three issues that the U.S. Congress has recently taken, or will most likely take, action on in the year ahead: access to federally funded research, net neutrality, and curbing government surveillance. The agenda continues to include a watch list of policy issues of great concern to academic librarians. Issues on the watch list are fair use, "making available" right, preservation and reproduction exceptions, orphan works, and the Digital Millennium Copyright Act.

As a member of the Open Access Working Group (OAWG), ACRL joined ten other groups in sending letters to the chairman of the House Committee on Science, Space, and Technology-Subcommittee on Research and Technology to express strong opposition to language contained in Title III, Section 302 of the proposed "Frontiers in Innovation, Research, Science, and Technology Act of 2013" or the FIRST Act. ACRL encouraged association members to contact their members of Congress to express opposition to the legislation. In June 2014, OAWG members additionally sent a letter to the California state legislature supporting open access legislation in that state.

ACRL continues to be an active partner with ALA and the Association of Research Libraries (ARL) in the LCA. Over the course of the past year, LCA has taken action on a number of important issues by issuing comments on pending legislation and court cases, joining briefs, 
and releasing papers and guides on a wide range of copyright and fair use issues, including the Google Book Search case, copyright in Europe, creativity and innovation in the digital environment, the Marrakesh Treaty, rights of authors to control dissemination of their work across networks such as the Internet, HathiTrust, and section 512 of the Digital Millennium Copyright Act.

In March 2014, ACRL additionally joined ALA in sending two letters to South Carolina Legislators expressing deep concern about the proposal to impose financial penalties on the College of Charleston and the University of South Carolina Upstate for offering classes that included texts dealing with sexual orientation and gender.

ACRL joined nine other national higher education and library organizations in July 2014 to file joint public comments urging the Federal Communications Commission (FCC) to adopt the legally enforceable network neutrality rules necessary to fulfill library missions and serve communities nationwide. The association additionally urged members to add their voices to the FCC public comment period on the issue.

\section{Partnerships with Higher Education}

As the higher education association for librarians, ACRL continues to work with partner groups to strengthen both partnerships and the profession. The association collaborated with members of the Council of Higher Education Management Associations to offer the 2013 Women's Leadership Institute. This program brought together mid-level administrators from across campus functions to share experiences, develop a better understanding of the campus as a workplace and culture, and create new networks and networking skills.

As mentioned in the Value of Academic Libraries section of this report, the Association for Institutional Research and the Association of Public and Land-grant Universities partnered with ACRL to receive a National Leadership Demonstration IMLS Grant for the ongoing "Assessment in Action (AiA): Academic Libraries and Student Success" project.

ACRL maintains liaison relationships with a number of higher education associations through the Liaisons Assembly. ACRL currently has liaison relationships with the American Anthropological Association (AAA), American Association for the Advancement of Science (AAAS), American Association of Community Colleges (AACC), American Council of Learned Societies (ACLS), American Political Science Association (APSA), American Sociological Association (ASA), Association for Information Science and Technology (ASIS\&T), Association for Library and Information Science Education (ALISE), Association for the Study of African American Life and History (ASALH), Council of Independent Colleges (CIC), EDUCAUSE Learning Initiative (ELI), Modern Language Association (MLA), National Council for Accreditation of Teacher Education (NCATE), National Resource Center for The First-Year Experience and Students in Transition (NRC-FYEST), National Women's Studies Association (NWSA), Society for College and University Planning (SCUP), and Society for Information Technology and Teacher Education (SITE).

ACRL also maintains close working relationships with a variety of additional associations including the American Council of Learned Societies (ACLS), American Institutes for Research (AIR), Association of Public and Land-grant Universities (APLU), Association of Research Libraries (ARL), 


\section{Neet the IORL Stialf}

Coalition for Networked Information (CNI), Council of Higher Education Management Associations (CHEMA), International Federation of Library Associations (IFLA ), and Scholarly Publishing and Academic Resources Coalition (SPARC).

\section{Organizational Effectiveness and Vitality}

ACRL seeks to acquire the fiscal resources, staff expertise, and organizational structure necessary to advance the association's Plan for Excellence.

\section{ACRL Staff}

During the 2014 fiscal year, ACRL Program Officer Lindsay Bosch left the association to pursue other opportunities. Allison Payne was promoted from program coordinator to program officer in April 2014. See the Choice entry in the publications section earlier in this report for details on staffing changes to ACRL's Connecticut office.

Many of you have had phone and e-mail contact with ACRL's staff, of which there are 15.75 ALAapproved FTE positions at headquarters. Here's your chance to put a face with that voice or e-mail signature. Below is a listing of current ACRL staff members (including two of ACRL's Choice 23.5 FTE staff) with information about their responsibilities. Take a minute to "meet the staff."

ACRL's office hours are 8:30 a.m. to 4:30 p.m. (CST), Monday through Friday. All ALA staff have direct telephone lines. All prefixes are (312) 280-, followed by the four-digit extension. If you use the toll-free number (800-545-2433) you will be instructed to enter the extension of the person you wish to speak with.

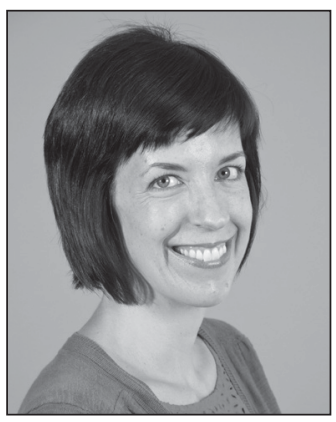

DAVID M. CONNOLLY, classified advertising coordinator/ editorial assistant. Manages job ads for C\&RL News in print; manages ALA JobLIST, the online career site ACRL operates jointly with American Libraries and ALA's Office of Human Resources Development and Recruitment; editor of the ALA JobLIST Direct e-newsletter; contact for information about subscriptions, job ads, and manuscript submissions for C\&RL News; produces ACRL Briefing Book. Phone: (312) 280-2513; e-mail: dconnolly@ala.org

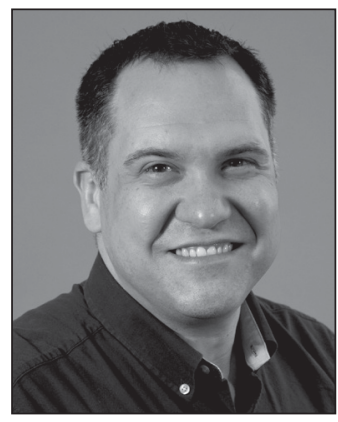




\section{Neet the IORL Stiffi}

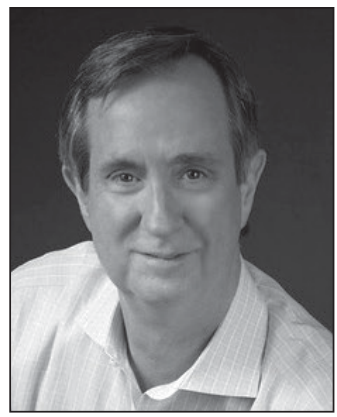

MARK CUMMINGS, CHOICE, editor and publisher. Develops new products from CHOICE's core content; handles magazine and other product advertising sales, subscription services, and marketing promotions for $C H O I C E$ and ACRL serial publications; oversees CHOICE Reviews Online; oversees Resources for College Libraries. Phone: (860) 347-6933; e-mail: mcummings@ala-Choice.org

MARY ELLEN K. DAVIS, executive director. Directs activities of the ACRL and CHOICE offices; coordinates policy implementation and strategic planning; prepares ACRL's budgets; ex-officio member of ACRL's Executive Committee and Board of Directors; serves as official contact for higher education organizations; grants fundraising development and approval. Phone: (312) 280-3248; e-mail: mdavis@ala.org
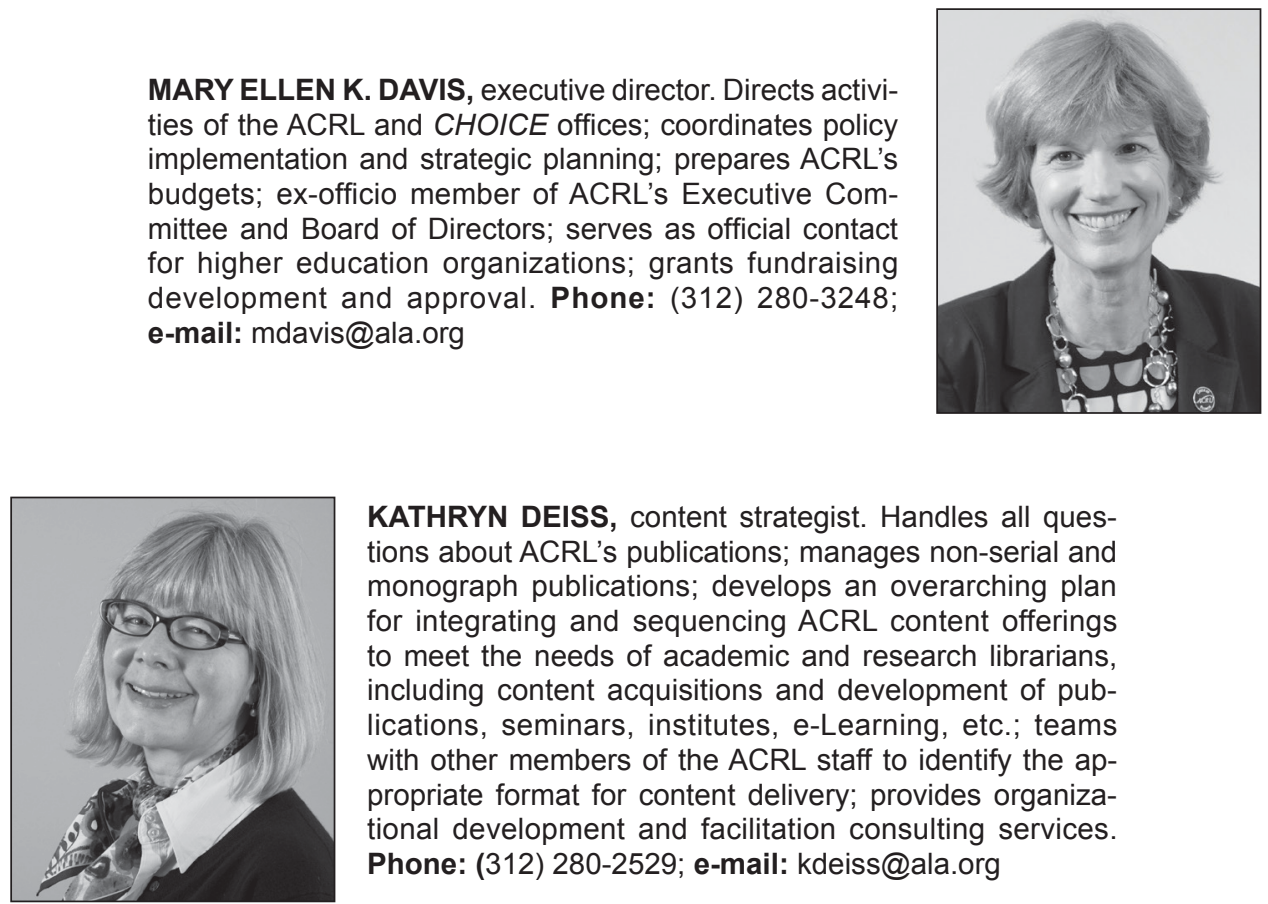

KATHRYN DEISS, content strategist. Handles all questions about ACRL's publications; manages non-serial and monograph publications; develops an overarching plan for integrating and sequencing $A C R L$ content offerings to meet the needs of academic and research librarians, including content acquisitions and development of publications, seminars, institutes, e-Learning, etc.; teams with other members of the ACRL staff to identify the appropriate format for content delivery; provides organizational development and facilitation consulting services. Phone: (312) 280-2529; e-mail: kdeiss@ala.org

DAVID FREE, editor-in-chief of College and Research Libraries News/marketing and communications specialist. Responsible for content and production of C\&RL News in print and online; develops marketing and communications plans for ACRL programs, publications, and services; coordinates press releases and promotional activities; coordinates ACRL's standards and guidelines. Phone: (312) 280-2517; e-mail: dfree@ala.org

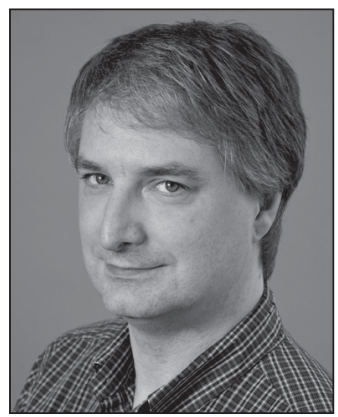




\section{Ileet the IOTRL Stitif}

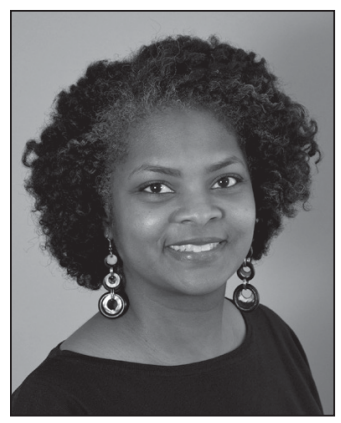

ANN-CHRISTE GALLOWAY, production editor. Copy and layout editor for C\&RL News in print and online. Writes "People in the News" and "Grants and Acquisitions" for C\&RL News. Phone: (312) 280-2524; e-mail: agalloway@ala.org

MEGAN GRIFFIN, program officer. Contact for section executive committees, rosters, and appointments; oversees ACRL's ALA Annual Conference programs and Communities of Practice special events and activities; prepares ACRL's ballots for the ALA annual elections. Phone: (312) 280-2514; e-mail: mgriffin@ala.org

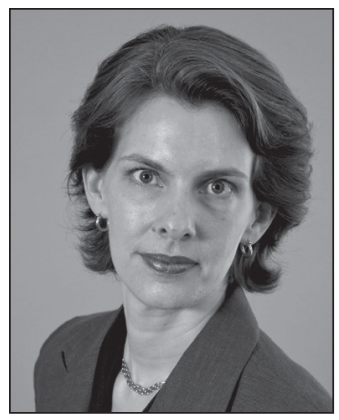

KARA MALENFANT, senior strategist for special initiatives. Coordinates ACRL's government relations advocacy, scholarly communication activities, Value of Academic Libraries initiative; teams with others on staff to provide consulting services on organizational development and use of ACRL's Standards for Libraries in Higher Education. Phone: (312) 280-2510; e-mail: kmalenfant@ala.org

DAWN MUELLER, senior production editor. Manages and produces all non-serial publications; develops and maintains ACRL's website; manages production of C\&RL, RBM, and section newsletters; primary design and production of all ACRL brochures and flyers. Phone: (312) 280-2516; email: dmueller@ala.org

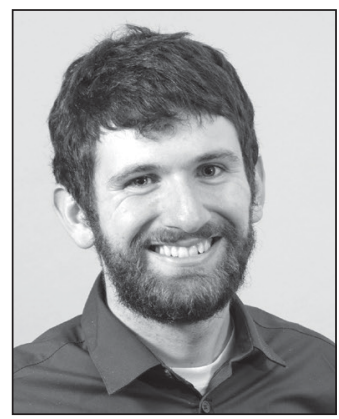

CHASE OLLIS, program coordinator. Manages ACRL's awards program; contact for ACRL Chapters; contact for discussion and interest groups; assists with professional development events. Phone: (312) 280-2521; e-mail: collis@ala.org 


\section{Neet the 1ORLS Stiflf}

TORY ONDRLA, conference supervisor. Manages logistics for ACRL professional development events including the ACRL Conference, preconferences, workshops, institutes, and ACRL Board functions. Phone: (312) 280-2515; e-mail: tondrla@ala.org
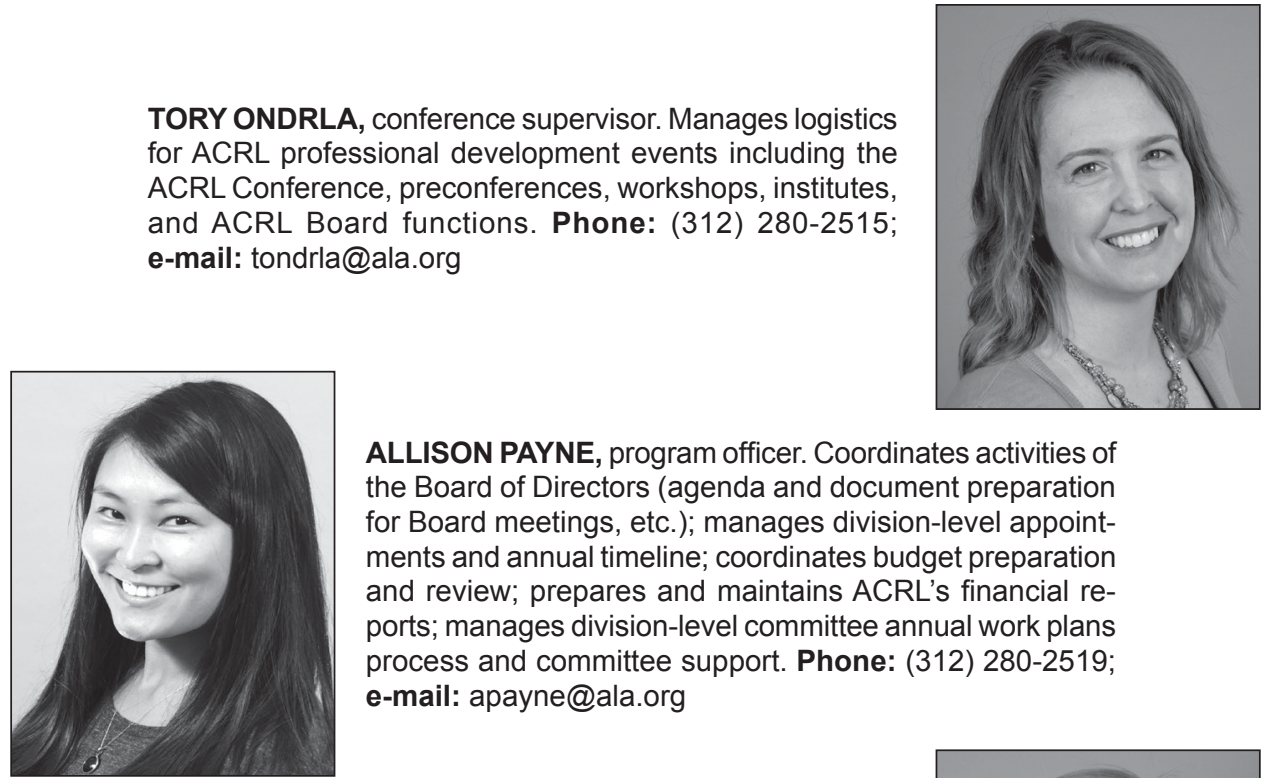

ALLISON PAYNE, program officer. Coordinates activities of the Board of Directors (agenda and document preparation for Board meetings, etc.); manages division-level appointments and annual timeline; coordinates budget preparation and review; prepares and maintains ACRL's financial reports; manages division-level committee annual work plans process and committee support. Phone: (312) 280-2519; e-mail: apayne@ala.org

MARY JANE PETROWSKI, associate director. Serves as chief operating officer for ACRL; coordinates ACRL membership promotion and retention activities; coordinates Friends of ACRL; coordinates advisory services, leader orientation, and mentoring programs; manages the ACRLMetrics service and ACRL's Academic Library Trends and Statistics program. Phone: (312) 280-2523; e-mail: mpetrowski@ala.org
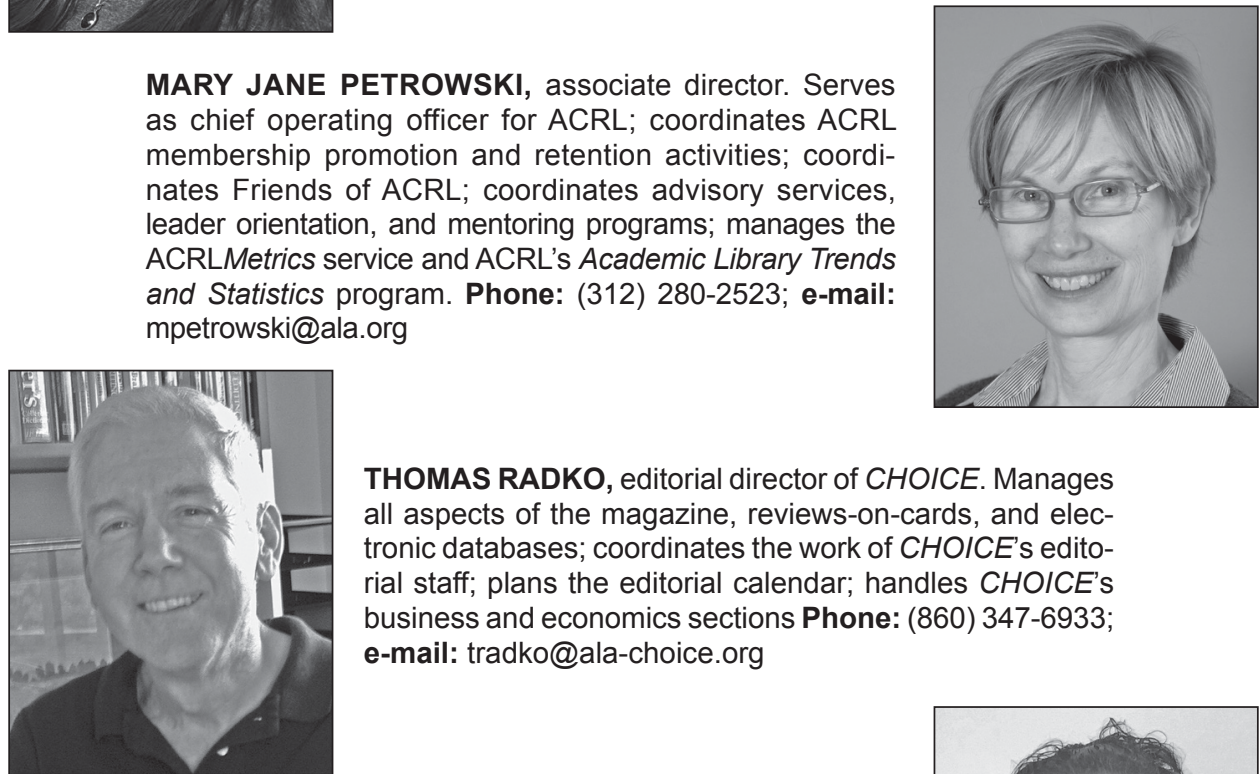

THOMAS RADKO, editorial director of $\mathrm{CHOICE}$. Manages all aspects of the magazine, reviews-on-cards, and electronic databases; coordinates the work of $\mathrm{CHOICE}$ 's editorial staff; plans the editorial calendar; handles $\mathrm{CHOICE's}$ business and economics sections Phone: (860) 347-6933; e-mail: tradko@ala-choice.org

ELOIS SHARPE, program coordinator. Assists with division-level appointments and annual timeline; coordinates ACRL meeting scheduling for ALA conferences; coordinates donations processing; assists with Board of Directors and Budget and Finance Committee support; contact for virtual meeting scheduling. Phone: (312) 280-5277; e-mail: esharpe@ala.org

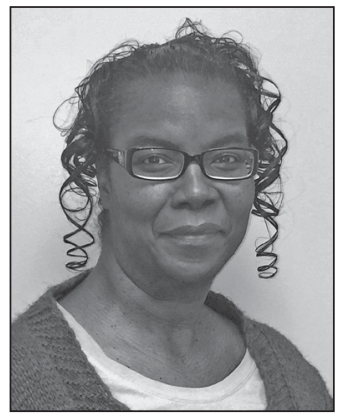




\section{ACRL Sponsorships for 2014}

ACRL expresses its sincere appreciation to the following sponsors for their generous donations to the various programs and events we have offered throughout the year. Thanks to your support, ACRL members benefited from enhanced programs and services this year.

\section{Colleagues}

Cum Laude (\$15,000-19,999)

Sage Publications

University of Pittsburgh Libraries

YBP Library Services

Mortar Board (\$10,000-14,999)

Alexander Street Press

West Virginia University Libraries

Dean's List $(\$ 5,000-9,999)$

EBSCO Information Services

IOP Publishing, Inc.

Kansas State University Libraries

Pennsylvania State University Libraries

ProQuest

University of Wyoming Libraries

Honor Roll (\$750-4,999)

AAAS

Adam Matthew Digital

American Society for Mechanical Engineers

Antiquarian Booksellers' Association of

America, Inc.

Appalachian State University C. G. Belk Library

Asia Bookroom

Atlas Systems, Inc.

Aux Amateurs de Lirvres/Librarie Internationale Tuzot

Bauman Rare Books, Inc.

Baylor University

Black Caucus of the American Library Association

Bonhams

Brigham Young University Library

Caladex Logistics
Honor Roll (continued)

Casalini Libri, S.P.A.

Colby College Libraries

Columbia University Libraries

Dartmouth College

Elsevier

Emerald Group Publishing Limited

Emory University Libraries

Geographic Research/Simply Map

The George Washington University Libraries IEEE

James Cummins Bookseller

Jarndyce Antiquarian Booksellers

John Wiley \& Sons, Inc.

Marquette University Libraries

Massachusetts Institute of Technology

Morgan \& Claypool Publishers

Nevada State Museum

North Carolina State University Libraries

Oberlin College Library

Orbis Cascade Alliance

Palmer School at Long Island University

Philadelphia Rare Books \& Manuscripts

Company

Preservation Technologies, L.P.

Royal Society of Chemistry

SAGE/CQ-Press

Santa Clara University Libraries

SPIE

Taylor \& Francis Group, LLC

Temple University Libraries

Thomson Reuters

University of Arizona

University of Arkansas Libraries

University of California-Irvine Libraries

University of Houston

University of Idaho

University of Illinois at Urbana-Champaign

University of Kansas Libraries 


\section{ACRL Sponsorships for 2014}

Honor Roll (continued)

University of Massachusetts Amherst Libraries

University of Michigan Library

University of Minnesota (Twin Cities) Libraries

University of Nevada-Las Vegas Libraries University of New Mexico, College of University Libraries and Learning Sciences University of Utah

University of Washington Libraries

Utah State University

Walter de Gruyter Stiftung

Washington University in St. Louis

Whitman College

Willamette University

William Reese Company

Wittenberg University

WT Cox Information Services

Donor (Up to \$749)

Antiquariat Botanicum

Archival Products

ArchivesSpace

Ars Libri

B \& B Rare Books, Ltd.

$B$ \& L Rootenberg Rare Books

Back of Beyond Books

Backstage Library Works

Bartleby's Books

Beth Lander

The Bibliographical Society of America

Bolerium Books

The Book Shop, LLC

Boston Rare Maps, Inc.

Bruce McKittrick Rare Books, Inc.

California Rare Book School

Carpe Diem Fine Books

Case Western Reserve University, Kelvin Smith Library

Coconut Rose Rare Books

CRC Press LLC

Dawson's Book Shop

De Wolfe \& Wood

Denison University Libraries, William

Howard Doane Library/Seeley G. Mudd

Learning Center

DePaul University
Donor (continued)

Eclectibles

Erasmus Boekhandel bv

Eric Chaim Kline Bookseller

Florida Atlantic University

Getty Research Institute

Hollinger Metal Edge

Jeff Hirsch Books

Jeffrey D. Mancevice, Inc.

Jett W. Whitehead Rare Books

Johanson Rare Books

John Windle Antiquarian Bookseller

Julia Gelfand

The Kelmscott Bookshop

Ken Lopez Bookseller

Ken Sanders Rare Books

Kenneth Karmiole, Bookseller, Inc.

Kevin F. Kelly Bookseller

Liber Antiquus

Linfield College

Little Sages Books

Loyola University of Chicago

Macalester College

Martayan Lan, Inc.

Michael R. Weintraub, Inc.

Musinsky Rare Books

Nat DesMarais Rare Books

The New England Journal of Medicine

Oak Knoll Books

Ohio Wesleyan University

Old Imprints

Otto Harrassowitz

Ovid Technologies

Palinurus Antiquarian Books

Priscilla Juvelis, Inc.

Puvill Libros

Roy Young Bookseller, Inc.

Royal Books, Inc.

Rulon-Miller Books

Simon Beattie

Southern Methodist University

Tavistock Books

Ten Pound Island Book Co.

Thomas A. Goldwasser Rare Books

University of California-Los Angeles Library,

Department of Special Collections

University of Montana, Mansfield Library

University of San Diego

W. B. Mason Company

Walkabout Books

Whitmore Rare Books 


\section{ICRL Boill of Directors, 2013-2014}

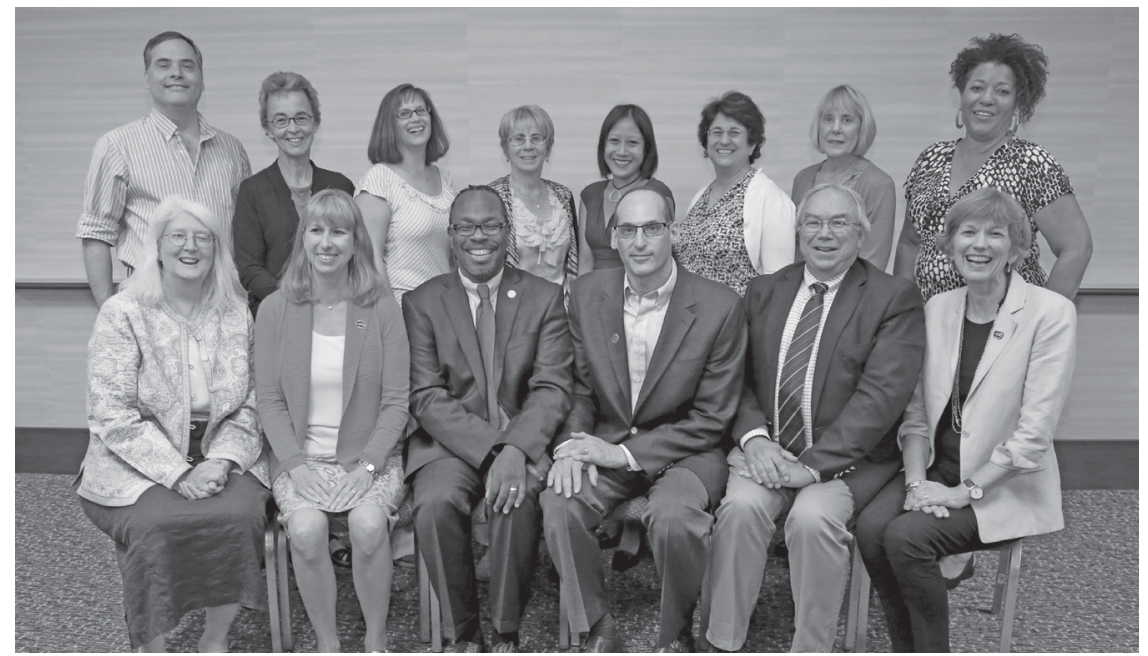

ACRL Board 2013-14 (I to r): (back) Mark Emmons, Susan Barnes Whyte, Julie Ann Garrison, Julia M. Gelfand, Marilyn Nabua Ochoa, Irene M. H. Herold, Mary Ann Sheble, Loretta R. Parham; (front) Cynthia K. Steinhoff, Karen Williams, Trevor A. Dawes, Steven J. Bell, Douglas K. Lehman, Mary Ellen K. Davis.

\section{ACRL Board of Directors, 2013-2014}

\section{President}

Trevor A. Dawes

Washington University

in St. Louis

\section{Vice-President/President-Elect}

Karen A. Williams

University of Arizona

Past-President

Steven J. Bell

Temple University

\section{Budget \& Finance}

Committee Chair

Cynthia K. Steinhoff

Anne Arundel Community College

ACRL Councilor

Douglas K. Lehman

Wittenberg University

Executive Director (Ex-officio)

Mary Ellen K. Davis

ACRL/ALA

\section{Directors-at-large}

Mark Emmons

University of New Mexico

Julie Ann Garrison

Grand Valley State University

Julia M. Gelfand

University of California-Irvine

Irene M. H. Herold

University of Hawaii-Manoa

Marilyn N. Ochoa

State University of New YorkOswego

Loretta R. Parham

Atlanta University Center

Woodruff Library

Mary Ann Sheble

Oakland Community College

Susan Barnes Whyte Linfield College 


\section{Fininincial Report}

\section{Cynthia K. Steinhoff}

Budget \& Finance Committee Chair

The ACRL Board of Directors, Budget and Finance Committee, and Executive Director carefully reviewed and monitored budget performance over the course of the 2013-2014 fiscal year (FY2014) in light of the slow recovery from the global economic recession. Despite budget challenges, ACRL's careful stewardship of its resources has allowed the association to serve its members well and advance its strategic initiatives. What follows is a summary of ACRL's budgetary performance

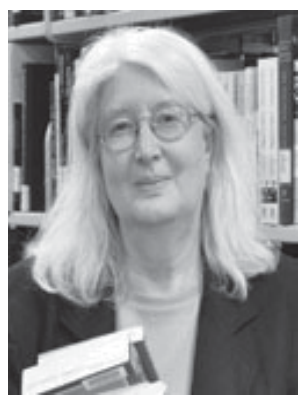
highlighting both operating revenue activity and budgetary outcomes.

\section{FY14 ACRL Budgetary Performance:}

\section{A Fiscal Year-End Summary as of August 31, 2014}

Due to the large swings in revenue caused by the biennial ACRL Conferences, comparisons with the most recent non-conference year are provided for ACRL. Choice revenues/expenses are reported separately to provide a clearer picture of the two operations.

\begin{tabular}{lcrrrr}
\hline $\begin{array}{l}\text { ACRL } \\
\text { TOTAL }\end{array}$ & $\begin{array}{c}\text { FY2014 } \\
\text { ACTUAL }\end{array}$ & $\begin{array}{c}\text { FY2014 } \\
\text { BUDGET }\end{array}$ & VARIANCE & $\begin{array}{r}\text { FY2012 } \\
\text { ACTUAL }\end{array}$ & VARIANCE \\
\hline $\begin{array}{l}\text { Revenues } \\
\text { Expenses }\end{array}$ & $\$ 2,204,536$ & $\$ 2,349,623$ & $(\$ 145,087)$ & $\$ 2,388,467$ & $(\$ 189,931)$ \\
\hline NET REVENUE & $(\$ 322,728)$ & $(\$ 574,629)$ & $\$ 251,901$ & $(\$ 240,408)$ & $\$ 82,320$
\end{tabular}

\begin{tabular}{lcccrr}
\hline CHOICE & FY2014 & FY2014 & & FY2013 & \\
TOTAL & ACTUAL & BUDGET & VARIANCE & ACTUAL & VARIANCE \\
\hline Revenues & $\$ 3,030,955$ & $\$ 3,055,057$ & $(\$ 24,102)$ & $\$ 2,926,519$ & $\$ 104,436$ \\
Expenses & $\$ 3,063,119$ & $\$ 3,254,924$ & $\$ 191,805$ & $\$ 3,171,398$ & $(\$ 108,279)$ \\
\hline NET REVENUE & $(\$ 32,164)$ & $(\$ 199,867)$ & $\$ 167,703$ & $(\$ 244,880)$ & $\$ 212,716$
\end{tabular}

\section{Factors Affecting Budget Outcomes}

Fiscal year 2013-2014 closed with better than budgeted net revenues thanks to careful budgeting and continuous monitoring and adjustment of expenses by the ACRL Board of Directors, Budget and Finance Committee and the Executive Director to keep revenue and expense expectations in line with the ongoing effects of the national and global recession on ACRL's economic performance. Economic conditions have affected libraries, higher education and the nonprofit sector in general, and reduced resources available to purchase association goods and services.

It should be noted that in non-conference years, ACRL spends money to plan the next conference but does not recognize revenue from registration fees, exhibits sales, and other income generated by the conference until the conference is held. FY14 expenses included $\$ 181,447$ related to early planning for the ACRL 2015 Conference in Portland. 


\section{ACRL Revenues}

As with other years, some categories performed better than others, contributing to revenue growth in some budget lines and deficits in others. Highlights in revenue and expense budget lines include:

- Classified advertising revenues continued to perform well, exceeding budget by $15.9 \%$. Online product ad sales were robust as well, exceeding budget by $44.78 \%$. This is clearly a growth area but does not offset the declining trend in print ad revenues, which were under budget by $11.86 \%$. Additionally, online advertising does not generate as much revenue as print ads have done in the past.

- ACRL's consulting service grossed $\$ 61,450$ in revenues or $1.57 \%$ better than budgeted. Consulting benefits the library community and has been a strong revenue generator for the past 2 years. The outlook for consulting services in FY2015 is good.

- Sales of ACRL's academic library statistics products generated $\$ 95,461$ in revenue, better than budget by $\$ 8,502$, or $9.78 \%$, which allowed the project to break even after expenses.

- Book sales continued a pattern with sales below budget. Revenue of \$192,108 was $33.23 \%$ below budget due to fewer books being published and lower sales.

- Subscription revenue was $31.26 \%$ under budget. A decline was anticipated when College and Research Libraries moved to an online-only format, which was reflected in the budget for FY2014. However, additional subscriptions cancellations contributed to the revenue decline.

Other revenue sources that were below budgeted amounts include continuing education webinars ( $21.73 \%$ below budget, but still generating $\$ 97,613$ in gross revenues) and membership dues revenue of $\$ 648,844$ were below budget by $2.78 \%$ or $\$ 18,551$.

\section{ACRL Expenses}

- ACRL total expenses overall were $13.58 \%$ less than budgeted. Much of this was due to careful management of expenses by the ACRL staff. Specific areas in which savings were realized include:

- Salary and benefits savings were realized due to one position held vacant for part of the year and a reduction in the cost of employee benefits from $33 \%$ to $30.3 \%$ of salary.

- Costs associated with publications were $\$ 31,103$, or $3.56 \%$ less than budgeted.

- Overall membership services program costs were under budget by $22.54 \%$, or $\$ 269,354$, with $\$ 99,230$ of that amount coming from savings of placeholder funds budgeted for potential special opportunities projects relating to ACRL strategic initiatives.

- Education costs were also under budget, by $\$ 120,818$, or $15.17 \%$. Much of this savings came from fewer honoraria and other costs associated with holding the events.

- $\quad$ Printing and postage costs were lower than anticipated, resulting in a savings of $\$ 52,129$.

\section{ACRL Net Revenue}

ACRL's net revenue of $(\$ 322,728)$ is better than budgeted by $\$ 251,901$ and is the deficit that would be expected in a non-conference year. This brings ACRL's net asset balance to a healthy $\$ 4,324,706$, which will allow the association to adjust to changes in the environment, and to seek other strategic opportunities for the development of new programs and services. A big challenge is to identify a major initiative that could be funded with part of the net asset balance. Another challenge is to identify new projects that would generate net revenues. 


\section{Long-Term Investment (LTI)}

The ACRL Long-Term Investment (LTI) Fund balance, which includes award endowments, reflected the market's upswing. The LTI ended the year at $\$ 3,040,256$, an increase of $17.31 \%$ over FY2013. ACRL budgets some of the interest from the LTI to support strategic initiatives. Because of the strong performance of the operating budget, earnings from the LTI were not transferred to the FY2014 operating budget.

\section{The Future}

The current economic climate has depressed ACRL's traditional revenue from membership and publications, and that is expected to continue. Recovery from the recent recession is moving slowly. ACRL's membership did not substantially increase during the FY13 Conference year as has been the pattern in previous years, raising questions about what will happen during FY2015, when the ACRL Conference will be held in Portland, Oregon. Typically, ACRL membership has increased at least 3\% in a conference year; in FY13 membership increased less than one percent.

Future budgets will incorporate revenue from newer programs and services (e.g., workshops on using ACRL's new standards, consulting services, and increased opportunities for online advertising) and we will continue to look for additional revenue opportunities with programs and services that members need. While ACRL looks for ways to grow its revenue streams, the association has also been working to trim administrative expenses. Staff continues to look for ways to streamline procedures and automate processes. The goal is to moderate annual expenditures to be more in line with current revenue expectations, while aligning the budget to support the Plan for Excellence. With a net asset balance of $\$ 4.3$ million, ACRL is considering judicious spending of a portion of the balance to invest in sustainable new programs and services to retain and attract members.

\section{CHOICE}

CHOICE closed FY2014 with revenues of $\$ 3,030,955$, or $\$ 24,102(0.79 \%)$ less than budget. This amount is $\$ 104,436$ more than in FY2013. Total expenses were $\$ 3,063,119,5.89 \%$ less than budgeted. As a result, net revenues for the year were $(\$ 32,164)$, or $\$ 167,703$ better than budget and $\$ 212,716$ better than in FY2013.

Subscription revenue was helped by a larger than expected increase in subscriptions to Resources for College Libraries. Revenues for this product increased by $\$ 122,205$ over last year and by $\$ 49,438$ over budget. Other Choice products did not fare as well, with subscription declines in the magazine, Choice Reviews on Cards, and Choice Reviews Online. Overall subscription revenues were $\$ 1,341$ better than budget and $\$ 102,435$ more than FY2013 revenue.

Another bright spot for Choice this year was the ACRL/Choice webinar program. ACRL and Choice split the revenue for sponsored webinars, each earning \$18,325 in FY2014. Had the infrastructure been available, more webinars could have been scheduled. One month into FY2015, Choice had already booked and scheduled 26 webinars for a total of $\$ 127,000$ in revenue. This shows the desire of vendors to speak directly to customers, but it is too early to determine if this is temporary.

continued on p. 660 
ACRL Executive Summary 2013-2014 (unaudited; report as of Oct. 28, 2014)

\begin{tabular}{|c|c|c|c|}
\hline SOURCES OF REVENUE & $\begin{array}{r}\text { FY2013 } \\
\text { ACTUAL }\end{array}$ & $\begin{array}{l}\text { FY2014 } \\
\text { BUDGET }\end{array}$ & $\begin{array}{l}\text { FY2014 } \\
\text { ACTUAL }\end{array}$ \\
\hline \multicolumn{4}{|c|}{ OPENING RESERVE LEVELS AS OF SEPT. 1: } \\
\hline ACRL Operating Reserve Fund & $\$ 3,965,632$ & $\$ 4,647,434$ & $\$ 4,647,434$ \\
\hline $\begin{array}{l}\text { ACRL Long-Term Investment Fund } \\
\text { (including award endowments) }\end{array}$ & $\$ 2,333,568$ & $\$ 2,561,564$ & $\$ 2,561,564$ \\
\hline CHOICE Operating Reserve Fund & $\$ 3,294,551$ & $\$ 3,049,671$ & $\$ 3,049,671$ \\
\hline CHOICE Long-Term Investment Fund & $\$ 770,806$ & $\$ 823,273$ & $\$ 823,273$ \\
\hline TOTAL & $\$ 10,364,557$ & $\$ 11,081,942$ & $\$ 11,081,942$ \\
\hline $\begin{array}{l}\text { ACRL LTI Fund Appreciation } \\
\text { (excluding award endowments) }\end{array}$ & $\$ 56,636$ & $\$ 111,167$ & $\$ 73,710$ \\
\hline \multicolumn{4}{|l|}{ MEMBERSHIP DUES AND OTHER } \\
\hline Dues & $\$ 670,225$ & $\$ 667,395$ & $\$ 648,844$ \\
\hline Standards and Licensing Fees & $\$ 91,544$ & $\$ 38,500$ & $\$ 87,491$ \\
\hline Miscellaneous Donations & $\$ 0$ & $\$ 60,500$ & $\$ 8,000$ \\
\hline Awards & $\$ 13,700$ & $\$ 10,460$ & $\$ 14,700$ \\
\hline Special Events & $\$ 16,881$ & $\$ 16,320$ & $\$ 16,030$ \\
\hline Subtotal & $\$ 792,350$ & $\$ 793,175$ & $\$ 775,065$ \\
\hline \multicolumn{4}{|l|}{ PUBLICATIONS } \\
\hline CHOICE & $\$ 2,926,519$ & $\$ 3,055,057$ & $\$ 3,030,955$ \\
\hline$C \& R L$ & $\$ 132,306$ & $\$ 47,427$ & $\$ 40,751$ \\
\hline$C \& R L$ News & $\$ 512,322$ & $\$ 469,428$ & $\$ 518,085$ \\
\hline$R B M$ & $\$ 38,129$ & $\$ 35,515$ & $\$ 35,993$ \\
\hline Nonperiodical Publications & $\$ 157,621$ & $\$ 287,699$ & $\$ 192,108$ \\
\hline Library Statistics & $\$ 77,193$ & $\$ 86,959$ & $\$ 95,461$ \\
\hline Subtotal & $\$ 3,844,090$ & $\$ 3,982,085$ & $\$ 3,913,353$ \\
\hline \multicolumn{4}{|l|}{ EDUCATION } \\
\hline Institutes & $\$ 361,949$ & $\$ 302,641$ & $\$ 266,063$ \\
\hline ACRL Conference & $\$ 2,405,866$ & $\$ 0$ & $(\$ 26,026)$ \\
\hline Preconferences \& Workshops & $\$ 179,594$ & $\$ 162,019$ & $\$ 188,073$ \\
\hline Annual Conference Programs & $\$ 17,650$ & $\$ 16,000$ & $\$ 21,350$ \\
\hline Web CE & $\$ 76,534$ & $\$ 124,720$ & $\$ 97,613$ \\
\hline Subtotal & $\$ 3,041,593$ & $\$ 605,380$ & $\$ 547,073$ \\
\hline \multicolumn{4}{|l|}{ SPECIAL PROJECTS } \\
\hline Friends of ACRL-Restricted & $\$ 16,002$ & $\$ 7,185$ & $\$ 42,684$ \\
\hline Friends of ACRL-Operating & $\$ 0$ & $\$ 12,040$ & $\$ 0$ \\
\hline ACRL Excellence Fund & $\$ 0$ & $\$ 12,000$ & $\$ 0$ \\
\hline IMLS Grant & $\$ 65,748$ & $\$ 85,424$ & $\$ 79,704$ \\
\hline Total Revenue & $\$ 7,678,033$ & $\$ 5,404,680$ & $\$ 5,235,491$ \\
\hline CHOICE Revenue & $\$ 2,926,519$ & $\$ 3,055,057$ & $\$ 3,030,955$ \\
\hline ACRL Revenue without $C H O I C E$ & $\$ 4,751,514$ & $\$ 2,349,623$ & $\$ 2,204,536$ \\
\hline
\end{tabular}




\section{Fininncial Report}

\begin{tabular}{|c|c|c|c|}
\hline OBJECT OF EXPENSE & $\begin{array}{l}\text { FY2013 } \\
\text { ACTUAL }\end{array}$ & $\begin{array}{l}\text { FY2014 } \\
\text { BUDGET }\end{array}$ & $\begin{array}{l}\text { FY2014 } \\
\text { ACTUAL }\end{array}$ \\
\hline \multicolumn{4}{|l|}{ MEMBERSHIP ACTIVITIES } \\
\hline Membership Services* & $\$ 108,564$ & $\$ 190,078$ & $\$ 121,667$ \\
\hline Executive Committee \& Board & $\$ 168,535$ & $\$ 257,319$ & $\$ 218,961$ \\
\hline Advisory & $\$ 46,296$ & $\$ 51,305$ & $\$ 45,117$ \\
\hline Standards Distribution & $\$ 44,545$ & $\$ 26,111$ & $\$ 15,050$ \\
\hline Awards & $\$ 34,915$ & $\$ 31,697$ & $\$ 41,866$ \\
\hline Chapters & $\$ 15,032$ & $\$ 21,393$ & $\$ 22,444$ \\
\hline Committees and Interest Groups & $\$ 114,868$ & $\$ 122,922$ & $\$ 98,744$ \\
\hline Sections & $\$ 76,075$ & $\$ 80,638$ & $\$ 92,409$ \\
\hline$C \& R L$ Over Revenue & $\$ 66,996$ & $\$ 66,742$ & $\$ 63,257$ \\
\hline$C \& R L$ News Over Revenue & $\$ 0$ & $\$ 19,531$ & $\$ 0$ \\
\hline Liaisons to Higher Ed. Organizations & $\$ 39,856$ & $\$ 55,397$ & $\$ 40,142$ \\
\hline Special Events & $\$ 23,121$ & $\$ 34,417$ & $\$ 25,219$ \\
\hline Information Literacy & $\$ 858$ & $\$ 8,694$ & $\$ 43,648$ \\
\hline Scholarly Communication & $\$ 64,473$ & $\$ 76,069$ & $\$ 67,354$ \\
\hline Value of Academic Libraries & $\$ 16,354$ & $\$ 40,852$ & $\$ 3,134$ \\
\hline Government Relations & $\$ 28,044$ & $\$ 31,235$ & $\$ 20,290$ \\
\hline Scholarships & $\$ 53,345$ & $\$ 28,300$ & $\$ 18,250$ \\
\hline Annual Conference Programs & $\$ 48,945$ & $\$ 52,358$ & $\$ 51,409$ \\
\hline Subtotal & $\$ 950,822$ & $\$ 1,195,058$ & $\$ 988,961$ \\
\hline \multicolumn{4}{|l|}{ SPECIAL PROJECTS } \\
\hline Friends of ACRL-Restricted & $\$ 45,294$ & $\$ 7,185$ & $\$ 0$ \\
\hline Friends of ACRL-Operating & $\$ 41,116$ & $\$ 10,494$ & $\$ 49,387$ \\
\hline ACRL Excellence Fund & $\$ 0$ & $\$ 14,656$ & $\$ 0$ \\
\hline Subtotal & $\$ 86,410$ & $\$ 32,335$ & $\$ 49,387$ \\
\hline \multicolumn{4}{|l|}{ PUBLICATIONS } \\
\hline CHOICE & $\$ 3,171,398$ & $\$ 3,254,924$ & $\$ 3,063,119$ \\
\hline$C \& R L$ & $\$ 132,306$ & $\$ 47,427$ & $\$ 40,751$ \\
\hline$C \& R L$ News & $\$ 431,481$ & $\$ 469,428$ & $\$ 430,721$ \\
\hline$R B M$ & $\$ 28,903$ & $\$ 28,207$ & $\$ 29,884$ \\
\hline Nonperiodical Publications & $\$ 138,589$ & $\$ 245,197$ & $\$ 182,316$ \\
\hline Library Statistics & $\$ 109,366$ & $\$ 82,930$ & $\$ 95,157$ \\
\hline Subtotal & $\$ 4,012,043$ & $\$ 4,128,113$ & $\$ 3,841,948$ \\
\hline \multicolumn{4}{|l|}{ EDUCATION } \\
\hline Institutes & $\$ 293,699$ & $\$ 295,520$ & $\$ 265,764$ \\
\hline ACRL Conference & $\$ 1,703,081$ & $\$ 226,814$ & $\$ 155,421$ \\
\hline Preconferences \& Workshops & $\$ 154,783$ & $\$ 156,897$ & $\$ 194,328$ \\
\hline Web CE & $\$ 48,427$ & $\$ 117,314$ & $\$ 60,214$ \\
\hline Subtotal & $\$ 2,199,990$ & $\$ 796,545$ & $\$ 675,727$ \\
\hline \multicolumn{4}{|l|}{ FUNDED PROJECTS } \\
\hline IMLS Grant & $\$ 65,748$ & $\$ 85,424$ & $\$ 79,704$ \\
\hline IMLS Grant Cost Share & $\$ 37,153$ & $\$ 34,310$ & $\$ 34,361$ \\
\hline Total Expenses & $\$ 7,241,124$ & $\$ 6,179,176$ & $\$ 5,590,384$ \\
\hline CHOICE Expenses & $\$ 3,171,398$ & $\$ 3,254,924$ & $\$ 3,063,119$ \\
\hline ACRL Expenses without $C H O I C E$ & $\$ 4,069,726$ & $\$ 2,924,252$ & $\$ 2,527,263$ \\
\hline
\end{tabular}




\begin{tabular}{lccr}
\hline $\begin{array}{l}\text { NET REVENUE AND } \\
\text { FUND BALANCES }\end{array}$ & $\begin{array}{c}\text { FY2013 } \\
\text { ACTUAL }\end{array}$ & $\begin{array}{r}\text { FY2014 } \\
\text { BUDGET }\end{array}$ & $\begin{array}{r}\text { FY2014 } \\
\text { ACTUAL }\end{array}$ \\
\hline ACRL Net without CHOICE & $\$ 681,788$ & $(\$ 574,629)$ & $(\$ 322,728)$ \\
CHOICE Net & $(\$ 244,880)$ & $(\$ 199,867)$ & $(\$ 32,164)$ \\
\hline \hline & & & $\$ 0$ \\
Transferred to CHOICE LTI Fund & $\$ 0$ & $\$ 0$ & $\$ 0$ \\
Transferred to ACRL LTI Fund & $\$ 821,516$ & $\$ 831,653$ & $\$ 831,653$ \\
Mandated ACRL Operating Reserve & & &
\end{tabular}

\section{CLOSING RESERVE LEVELS AS OF AUG. 31:}

\begin{tabular}{|c|c|c|c|}
\hline ACRL Operating Reserve Fund & $\$ 4,647,421 *$ & $\$ 4,072,805$ & $\$ 4,324,706$ \\
\hline $\begin{array}{l}\text { ACRL Long-Term Investment Fund } \\
\text { (including award endowments) }\end{array}$ & $\$ 2,561,563$ & $\$ 2,591,750$ & $\$ 3,040,256$ \\
\hline CHOICE Operating Reserve Fund & $\$ 3,049,672$ & $\$ 2,849,804$ & $\$ 3,017,508$ \\
\hline CHOICE Long-Term Investment Fund & $\$ 823,273$ & $\$ 816,241$ & $\$ 895,640$ \\
\hline TOTAL & $\$ 11,081,929$ & $\$ 10,330,600$ & $\$ 11,278,110$ \\
\hline
\end{tabular}

Notes: ACRL's fiscal year runs from September 1 through August 31. Actual numbers shown are rounded from two decimal places; therefore, subtotals may not precisely represent column totals due to rounding. Salaries and operating costs are allocated to each budget project and are not presented as a separate line item.

*Adjustments made by ALA auditing after the publication of the FY13 Annual Report resulted in a change to yearend operating reserve fund, also reflected in the FY14 opening reserve level.

continued from p. 657

Licensing, also called royalty income, stems from three sources: licenses for Choice reviews, licensing of Resources for College Libraries to various platforms, and several miscellaneous categories generating small amounts of revenue. Overall, total licensing revenue at $\$ 758,902$ was $\$ 3,069$ more than budgeted, but still $\$ 6,593$ less than in FY2013.

Advertising revenue for Choice continued its trend of the past few years. Publishers are less interested in print advertising. While they are interested in online advertising, it commands lower price points. Digital advertising revenue increased by $32 \%$ over 2013 and surpassed the budgeted amount by $21 \%$. Overall advertising revenue was $\$ 22,006$, or $4.06 \%$ below budget, and declined by $\$ 28,875(5.26 \%)$ from last year.

Choice expenses performed better than budget by $\$ 191,805$, or $5.89 \%$. Expenses were $\$ 108,279$ lower than FY13. Changes in personnel, the discontinuation of two non-performing products, less expensive benefits, and travel reductions helped to contain expenses, as did careful budget monitoring. These savings were partially offset by larger than budgeted depreciation costs for recent technology investments.

The challenge for Choice in the future is to develop new products and services that can offset losses in subscription revenue. 


\section{Fininncial Report}

\section{Budget \& Finance Committee, 2013-2014}

Cynthia K. Steinhoff, Anne Arundel Community College, chair Carolyn Henderson Allen, University of Arkansas

Fannie M. Cox, University of Louisville

Brian J. Doherty, New College of Florida

Rosita E. Hopper, Johnson \& Wales University

Diane G. Klare, Wesleyan University

Kim Leeder, College of Western Idaho Library

John A. Lehner, University of Houston

Kevin Wade Merriman, Yale University

Judith C. Russell, University of Florida

Edwin C. Schroeder, Yale University

Karen A. Williams, University of Arizona, ex-officio

Mary Ellen K. Davis, ACRL/ALA, ex officio

Allison Payne, ACRL/ALA, staff liaison
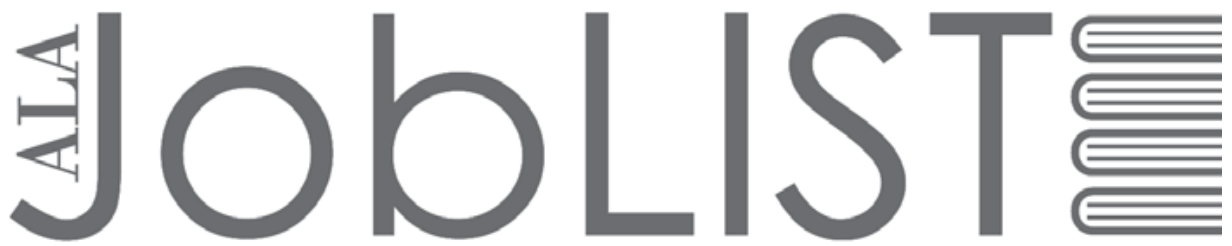

The \#1 source for jobs in Library and Information Science and Technology

\section{WHERE JOB SEEKERS AND EMPLOYERS GET RESULTS}

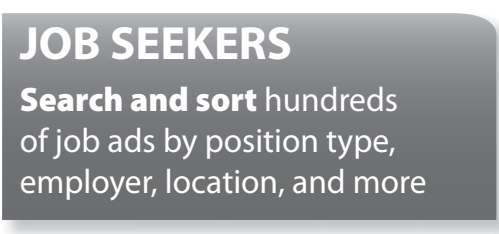

\section{EMPLOYERS}

Strengthen your candidate poolALA reaches the most engaged professionals and students

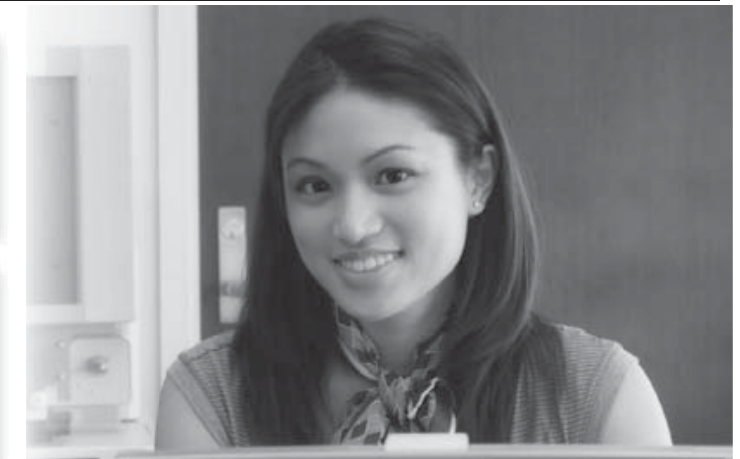

\section{ALA libreriaries HRDR nens ACRL}

\section{joblist.ala.org}

